\title{
Evolution of Microstructure During Double-Sided Friction Stir Welding of Microalloyed Steel
}

\author{
T.N. BAKER, S. RAHIMI, B. WEI, K. HE, and N.A. McPHERSON \\ Microstructures observed by analytical scanning and transmission electron microscopy in the \\ overlap region of a double-sided friction-stir-welded microalloyed steel (EH46) were recorded in \\ detail. They are compared with microstructures in the thermomechanically affected region of the \\ weld and with the base material. The differences suggest that the overlap region has been stirred \\ in the single-phase ferrite, and consists mainly of small equiaxed ferrite grains with \\ strain-induced precipitates, while the thermomechanically affected zone was processed in the \\ austenite-ferrite-phase field, resulting in a mixture of bainite lath packets and ferrite grains. The \\ almost complete absence of pearlite or cementite in the overlap region has led to the suggestion \\ that it dissolved during friction stir welding, providing carbon for strain-induced precipitation. \\ Also, in the complex microstructures of the overlap region, ferrite grains containing a high \\ density of cell-like structures were observed, some of them having precipitates nucleated on their \\ intersections. This implies that strain-induced continuous dynamic recrystallization has \\ occurred.
}

https://doi.org/10.1007/s11661-019-05184-2

(C) The Author(s) 2019

\section{INTRODUCTION}

FRICTION stir welding (FSW) is now a mature procedure for joining the light metals and alloys of aluminum, magnesium, and titanium. ${ }^{[1,2]}$ More recently, attention has been paid to steels, through work initially on stainless steels ${ }^{[1,3-5]}$ and on mild and microalloyed steels. ${ }^{[5-9]}$ This has been achieved through improvements in tools, in particular polycrystalline boron nitride (PCBN) pins for use at higher temperatures, in the range $1273 \mathrm{~K}$ to $1473 \mathrm{~K}\left(1000{ }^{\circ} \mathrm{C}\right.$ to $\left.1200{ }^{\circ} \mathrm{C}\right)$. The majority of this research has been concentrated on alloys with plate thicknesses $\leq 10 \mathrm{~mm}$, where the weld can be accomplished in a single pass. The plate thickness which can be welded is limited by the length of the tool, which for PCBN pins, often the pin of choice for FSW of steels, is $\sim 8 \mathrm{~mm}$. To weld thicker alloys, the plates must be turned after the first pass has cooled to ambient, and a second pass made to complete the weld. ${ }^{[10]}$ The

T.N. BAKER and N.A. McPHERSON are with the Department of Mechanical and Aerospace Engineering, University of Strathclyde, 75 Montrose Street, Glasgow, G1 1XJ, UK. S. RAHIMI is with the Advanced Forming Research Centre (AFRC), University of Strathclyde, 85 Inchinnan Drive, Inchinnan, Glasgow, PA4 9LJ, UK. Contact e-mails: salah.rahimi@strath.ac.uk, salah.rahimi@hotmail.co.uk B. WEI and K. HE are with the Electron Microscopy Laboratory, Advanced Research Centre, Central South University, Changsha, 410083, Hunan, China.

Manuscript submitted November 8, 2018.

Article published online March 22, 2019 material forming the weld undergoes a complex thermomechanical treatment as a result of friction generated between the tool and the work-piece. In this process the plastically deformed material under the shoulder is rearranged by the tool's rotation and sideways movement. This results in improved mechanical and metallurgical weld properties, and normally, a lower level of residual stress compared to other methods of welding. ${ }^{[1-13]}$ Several publications describe the results of this double-sided FSW technique for steels. ${ }^{[10,14,15]}$ The study reported in Reference 10 investigated the dominant deformation mechanisms by looking at the evolution of microstructure and crystallographic texture in different regions of the weld, but has not considered in detail the evolution of microstructure at submicron scales.

A variety of terms are used in the literature to describe different microstructural zones observed during FSW of different materials. ${ }^{[16]}$ For a single pass FSW, the postweld microstructural zones are classified as (i) unaffected base material (BM), (ii) the heat affected zone (HAZ), (iii) the thermomechanically affected zone (TMAZ). The TMAZ extends across the weld from the HAZ on the advancing side (AS) to the HAZ on the retreating side (RS), which has frequently been subdivided to subzones depending on microstructure. The central part of the TMAZ is generally known as the stirred zone (SZ), or nugget (NG). An area immediately below the upper face of the weld, known as the shoulder affected zone (SAZ), in which the material is subjected to strains induced by the shoulder along the welding 
direction (WD), as well as the in-plane strains induced by the tool's rotation.

From the published studies, ${ }^{[1,5,9,10,15,17]}$ it is evident that a complex microstructure develops during the single-sided FSW process, and this appears to be exacerbated in the double-sided FSW. Most of the previous microstructural observations on FSW steels have been carried out with optical and scanning electron microscopy (SEM), supplemented with EDX and EBSD information. While some Transmission electron microscopy (TEM) studies have been reported, they have tended to be concerned with FSW which occurred entirely in the two-phase $\alpha / \gamma$ field where bainite is the most frequently reported microstructure. In this double-sided FSW work, several different zones, comprising wide variations in microstructure, have been identified.

Recently, ${ }^{[10,15]}$ an attempt has been made to explain differences in the hardness levels, by considering the variations in microstructure in these regions. In addition to the above zones in TMAZ, in the double-sided FSW investigated in the current study, there exists a zone in the center of the stir zone in which the material experiences the welding process twice, where the second weld pass is partially (i.e., depending on the probe length) overlapping with the root of the first weld pass. ${ }^{[14]}$ In this study, this region is referred to as the interaction zone (IZ). The hardness levels varied from 180 to $200 \mathrm{HV}$ in BM, in the region of the TMAZ surrounding the IZ in both weld passes $\sim 250 \mathrm{HV}$, in the SZ (i.e., center of the weld) $\sim 320 \mathrm{HV}$, but where the ultrafine ferrite grain size of $0.8 \mu \mathrm{m}$ was recorded in the $\mathrm{IZ}, \sim 200 \mathrm{HV} \cdot{ }^{[10]}$

The BM consisted of banded ferrite-pearlite grains, the TMAZ's, mixtures of ferrite and upper bainitic lath structures with films at their boundaries, and dislocations and precipitates in the interiors. The number of ferrite grains in the TMAZs increased as the weld approached the IZ, while the IZs comprised mainly of recrystallized equiaxed ferrite grains, in the range of 0.5 to $3 \mu \mathrm{m},{ }^{[10]}$ containing subgrains and cells, together with dislocations interacting with fine-scale precipitates. ${ }^{[15]}$

This preliminary microstructural investigation raised a number of questions, which necessitate a more comprehensive exploration of the microstructure. These include the possible retention of some transition metal carbides -25 to $100 \mathrm{~nm}$ in size, identified in $\mathrm{BM}$, in the IZ, and an understanding of the role they have in developing the microstructure of IZ. Also, if, as was proposed, ${ }^{[10,15]}$ the FSW temperature associated with IZ was below $\mathrm{Ac}_{1}$, and below $\mathrm{Ac}_{3}$ during TMAZ formation, then it is important to understand the dissolution of pearlite in the banded $\mathrm{BM}$ during the processing, and in what form that carbon assumes in the weld zone.

Santos et al. ${ }^{[18]}$ have reported a martensite/austenite $(\mathrm{M} / \mathrm{A})$ phase in FS welds, and while it may have a role in influencing the microstructure in the TMAZ zones, this was not investigated in the previous studies. ${ }^{[10,15]}$ In the TMAZ of both weld passes, lath colonies were present, often with significant dislocation densities and many fine precipitates, 6 to $10 \mathrm{~nm}$ in size. Also, the lath boundaries often served as nucleation sites for larger precipitates. Some of the lath interiors contained dislocations present as partial networks, suggesting an early stage of recovery. It is important to ascertain if the fine precipitates nucleated after the dislocations had formed cells, and whether sufficiently high strains developed during FSW to unpin the dislocations associated with the particles. Another observation was that particles and dislocations were present in some of the IZ-recrystallized grains. The selected area electron diffraction (SAED) patterns indicated that the grains were separated by high-angle boundaries. In other cases, multiple spots were present in the SAED patterns, indicating subgrains separated by low-angle boundaries.

The crystallographic textures of the three zones were determined and considered in depth. ${ }^{[10]}$ It was shown through EBSD investigations that the deformations in both TMAZ and IZ were shear dominated by $D_{1}\{\overline{1} \overline{1} 2\}\langle 111\rangle$ and $D_{2}\{11 \overline{2}\}\langle 111\rangle$ simple shear texture components. However, a comprehensive exploration of the IZ, TMAZ, and HAZ has revealed a more complex microstructure than considered in the earlier studies, ${ }^{\text {9,15] }}$ which cannot be explained by texture studies.

The FSW of microalloyed steel involves thermal impact, thermomechanical processing, phase transformation, and complex microstructural evolution which are not clearly understood. The solid-state phase transformation dictates the physical and mechanical properties of ferrous alloys, and information is lacking in this respect for the FSW of microalloyed steels, particularly with respect to the evolution of microstructural features such as carbide precipitates. This paper aims to present a clearer understanding of the evolution of subgrain-scale microstructural changes in a double-sided friction stir-welded microalloyed steel of type EH46.

\section{EXPERIMENTAL PROCEDURE}

The microalloyed steel plate used in this study was shipbuilding grade EH46 with chemical composition, taken from the plate certificate, as shown in Table I. Two plates of EH46 steel with $2000 \times 200 \times 14.5 \mathrm{~mm}$ $(L \times W \times T)$ dimensions were butted together with a square-edge weld preparation and friction stir welded. A TrifaltTM design MegaStir tool with a tungsten carbide shank of $25 \mathrm{~mm}$ in diameter at the shoulder, terminating in a pin made of PCBN was used. The pin was $8 \mathrm{~mm}$ long, with a base diameter of $4 \mathrm{~mm}$ and a 45 -deg tapered probe from either side, where the rotation direction was counter-clockwise.

The weld was produced under force control in two passes. The first weld pass was made at rotational speed of $200 \mathrm{rpm}$, transverse speed of $125 \mathrm{~mm} \mathrm{~min}^{-1}$ and with an average downward axial force of $55 \mathrm{kN}$. The tool was then moved over the BM, and the plate was cooled, unclamped, and turned after the first pass, so that the second pass started at ambient temperature. The second weld pass was then continued with the same tool rotation speed at $180 \mathrm{rpm}$, and identical transverse speed and downward axial force as those of the first weld pass. Both the weld and the tool were shielded with argon to restrict oxidation. Specific welding figures, 
Table I. Nominal Chemical Composition for EH46 Microalloyed Steel Used in This Study (Weight Percent)

\begin{tabular}{lcccccccccccccc}
\hline Element & $\mathrm{Fe}$ & $\mathrm{C}$ & $\mathrm{Si}$ & $\mathrm{Mn}$ & $\mathrm{P}$ & $\mathrm{S}$ & $\mathrm{Cr}$ & $\mathrm{Mo}$ & $\mathrm{Al}$ & $\mathrm{Nb}$ & $\mathrm{Ti}$ & $\mathrm{Ni}$ & $\mathrm{V}$ & $\mathrm{N}$ \\
\hline Wt Pct & bal. & 0.12 & 0.45 & 1.46 & 0.014 & 0.003 & 0.01 & $<0.01$ & 0.05 & 0.03 & 0.004 & 0.02 & 0.07 & 0.005 \\
\hline
\end{tabular}

Table II. Specific Parameters Implemented During the First and Second Weld Passes

\begin{tabular}{lcccc}
\hline & Rotation Speed (rpm) & Traverse Speed $\left(\mathrm{mm} \mathrm{min}^{-1}\right)$ & Heat Input $\left(\mathrm{kJ} \mathrm{mm}^{-1}\right)$ & Operating Condition \\
\hline Weld Pass 1 & 200 & 125 & 2.60 & position control at 55 kN \\
Weld Pass 2 & 180 & 125 & 2.34 & position control at 55 kN \\
\hline
\end{tabular}

representative of low heat input conditions, are given in Table II, where it is seen that there was a slight reduction in the rotation speed for the second side to prevent the tool overheating. This has manifested itself as a 10 pct reduction in the heat input, which was calculated from processing factors such as travel speed, tool rotation speed, and torque. ${ }^{[19]}$ The samples were taken from the areas of relative stability within the welded regions, i.e., out with the first and last $100 \mathrm{~mm}$.

Specimens with $30 \mathrm{~mm} \times 14.5 \mathrm{~mm}$ dimensions were cut from the center of double-sided weld cross section, in the plane perpendicular to the WD, and mechanically ground, and polished to a mirror-finish condition. Following surface preparation, the surface of a sample was etched with 4 pct Nital solution for 15 seconds and inspected by both optical and SEMs for general microstructure observation. Further, to distinguish the M/A phase, a two-step metallographic etching procedure developed by Alé et al. ${ }^{[20]}$ was employed on an additional mirror-finished sample. The first step involved two solutions, A (1 g sodium metabiosulphate, $100 \mathrm{ml}$ distilled water) and B (4 g picric acid, $100 \mathrm{~mL}$ pure ethanol), being mixed in a $1: 1$ proportion just before etching. The solution can only be used once, and the ideal etching time is 20 seconds. The second step involves electrolytic etching in a solution of $5 \mathrm{~g}$ of picric acid, $25 \mathrm{~g}$ sodium hydroxide, and $100 \mathrm{~mL}$ distilled water. An etching time of 100 to 140 seconds at $5 \mathrm{~V}$ is recommended. The result is that carbides are black, the $\mathrm{M} / \mathrm{A}$ constituents white, and ferrite, gray. Alé et al. ${ }^{[20]}$ found that the best SEM images were obtained in the backscattered mode.

Metallography was undertaken using Olympus GX-51 and Leica DMILM Microsystem optical microscopes. SEMs Hitachi S-3700N, Hitachi SU6600 field emission, and FEI Helios Nanolab 600i, all equipped with EDS (Oxford Instruments) were used for medium magnification observations of the microstructures.

TEM was used for detailed microstructural investigation with initially Philips EM400 TEM fitted with Phoenix EDAM IV EDX analyzer system and later with the FEI Tecnai TF20 with an EDX observing both carbon extraction replicas and foils. The latter were jet polished from 3-mm-dia. spark machined disks taken from specific regions of the FSW specimens. Foils examined by the FEI Tecnai TEM were first mechanically ground to a thickness of around $80 \mu \mathrm{m}$ from thin slices, followed by electropolishing in a Struers Tenpol-5 two-jet unit using an electrolyte of 10 pet perchloric acid, 30 pet 2-butoxyethanol and 60 pet ethyl alcohol, at $12 \mathrm{~mA}, 15 \mathrm{~V}$ and approximately $-15^{\circ} \mathrm{C}$ for the IZ. The TMAZ TEM samples were prepared using FEI Helios Nanolab 600i, a dual-beam-focused ion beam interfaced in an SEM system. It was not possible to prepare separate foils from the two welds comprising the overlap IZ. The schematic locations of these specimens are shown in Figure 1.

\section{RESULTS}

\section{A. Microstructural Analysis}

Figure 1 is an optical micrograph of the weld cross section following the chemical etching. The welded area can be distinguished from the BM due to its characteristic hour-glass shape appearance that is darker than the rest of the surface. The AS and RS of both weld passes are on the same side of the micrograph shown in Figure 1. The double-sided weld in this study consists of the unchanged BM and the TMAZ. The TMAZ can further be classified into different subzones of SAZ, SZ, and IZ, shown in Figure 1, depending on microstructure. These zones and subzones are shown in Figure 1. The term 'stirred zone' (SZ) is perhaps not technically correct as the entire TMAZ, including the SZ, is experiencing the stirring process, but it has been used for the sake of simplicity. A region can be seen in the center of the SZs with an approximate thickness of 2 to $2.5 \mathrm{~mm}$. This appears to be equivalent to the overlapping section of the probe during second weld pass on the welded material from the first pass that is referred to as the IZ.

The chemical compositions of the BM, SZ, and the overlap region of the stir zone (i.e., IZ) are given in Table III. The analyses of BM and that of the SZ are in good agreement with the plate certificate shown in Table I. Analyses from the BM and the SZ were taken using inductively coupled plasma optical emission spectroscopy, ICP-OES. The IZ was too small to be analyzed by ICP-OES; therefore, the data were obtained 


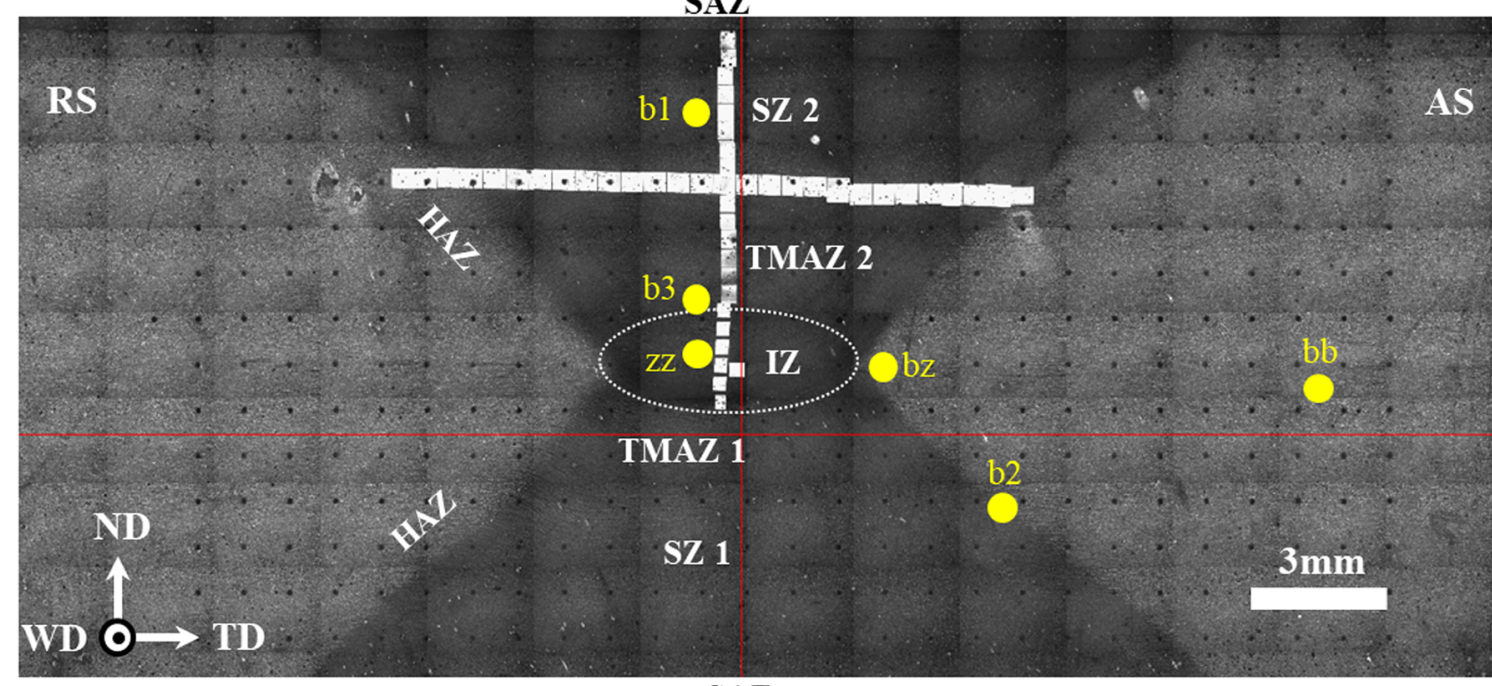

SAZ

Fig. 1-Optical micrograph of the transverse cross section of the double-sided friction-stir-welded plate. The WD is perpendicular to the plane of the micrograph. Note that the first weld pass is at the bottom and the second pass is at the top of the micrograph. Different regions are distinguished by adding 1 and 2 as suffix, respectively, for the first and the second weld passes. The advancing side (AS) and retreating side (RS) of both weld passes are identical. Samples for OM, SEM. and TEM microstructural analyses were taken from the areas highlighted by yellow circles labeled as bb for BM, b1 for the SZ of the second weld pass (i.e., single weld), b3 for TMAZ of the second weld pass, zZ for the IZ, b2 for HAZ of the first weld pass, and bz for an area in the HAZ at the proximity of the IZ (Color figure online).

using glow discharge optical emission spectroscope. The glow discharge analysis taken from the IZ did not provide nitrogen data and showed some differences in niobium and vanadium. The titanium was a residual and not a deliberate addition.

The microstructures of the FSW samples were explored at different areas of BM, BM/TMAZ, TMAZ, and IZ and labeled as b1, b2, b3, bb, bz, and $\mathrm{zz}$ in Figure 1. Thus a comparison can be made of the changes in the main features moving from the top of the TMAZ weld to the overlapped IZ, with BM. Figure 2(a) shows the banded ferrite-pearlite microstructure of the $\mathrm{BM}$ around area bb highlighted in Figure 1. The ferrite grain size varied in different areas of the $\mathrm{BM}$ from 18 to $\sim 25 \mu \mathrm{m}^{[10,15]}$ and the pearlite colonies, with an average size of $5 \mu \mathrm{m}^{[10]}$ are in normal cementite/ferrite arrays. The transformation of ferrite/pearlite microstructure in BM to bainite mixed separated by a layer of ferrite with a small fraction of degenerate pearlite (DP) is shown in Figure 2(b), which is taken from an interface between BM and TMAZ at area b2 in Figure 1. The dark bands of pearlite which are separated by lighter etched ferrite grains in Figure 2(c), show severe distortion around D, with some recrystallization evident at R1, while at R2, which is closer to the BM, no recrystallization has occurred.

In contrast to Figures 2(b) and 3(a) from the center of the SZ which is in the middle of TMAZ is mainly bainitic mixed with some ferrite. This region of the TMAZ was processed in the two-phase region and on cooling, the austenite transformed to bainite while the ferrite recrystallized from the BM average grain size of 25 to $\sim 5 \mu \mathrm{m}$. Ferrite grain boundaries are normally curved in the bottom of TMAZ, seen in Figure 3(b). Pearlite is present mainly in a degenerate form, and following the severe strains of FSW, the banded arrangement present in the parent plate has been replaced by a random distribution. The high-resolution micrograph of mainly equiaxed ferrite grains in Figure 3(c), show little evidence of pearlite, except possibly at DP (i.e., grains highlighted by arrows). The presence of cementite is difficult to discern. Other features in the BM, TMAZ, and IZ areas included $\mathrm{M} / \mathrm{A}$ etched as described earlier in the experimental procedure. In the IZ, Figure 3(d), M/A particles are considered to be carried over from the as-rolled BM plate, as the IZ region did not go above $\mathrm{Ac}_{1}$ during the FSW process. ${ }^{[10]}$

In Figure 4, strain-induced precipitation (SIP) is present in both the IZ and the TMAZ laths, which are separated by a very sharp boundary region. Many of the lath boundaries are decorated with particles $(\mathrm{P})$ and in some areas, such as that outlined by the white circle at $\mathrm{R}$, recrystallization within the laths is in place. Several of the TMAZ laths contain cell structure (CS).

Upper bainite laths, having 300 to $400 \mathrm{~nm}$ width, with precipitates on the lath boundaries at $\mathrm{P}$ and a high dislocation density within the laths are present in Figure 5. A square-shaped particle, $\sim 40 \mathrm{~nm}$ in size, located in a lath, is arrowed at LP, is probably retained from the original BM. In some laths, such as the regions 1,2 and 3 circled, cells are present. In this figure there is less evidence of SIP within the laths, which appear to be dominated by cells.

Following tilting experiments to reduce the dislocation contrast in some laths in a bainite packet, upper bainitic lath boundaries in Figure 6 show precipitates at different stages in the growth. At SP, individual particles on lath boundaries are resolved, whereas at ferrite, the particles have formed into continuous films. SIP is seen 
Table III. Results of Chemical Analyses Performed on Different Zones of the Weld

\begin{tabular}{lcccccccccccccc}
\hline Weld Zones & Fe & C & Si & Mn & P & S & Cr & Al & Nb & Ti & Ni & V \\
\hline BM & bal. & 0.12 & 0.45 & 1.48 & 0.013 & 0.003 & 0.018 & 0.045 & 0.036 & 0.004 & 0.023 & 0.067 & 0.006 \\
SZ & bal. & 0.12 & 0.45 & 1.44 & 0.014 & 0.003 & 0.01 & 0.05 & 0.030 & 0 & $<0.01$ & 0.070 & 0.005 \\
IZ & bal. & 0.127 & 0.45 & 1.44 & 0.014 & 0 & 0.007 & 0.049 & 0.026 & 0 & 0.018 & 0.101 & - \\
\hline
\end{tabular}

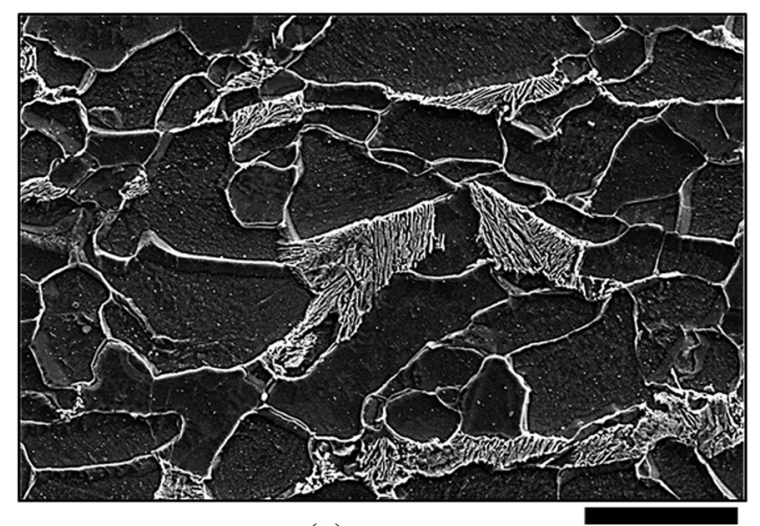

(a)
$10 \mu \mathrm{m}$

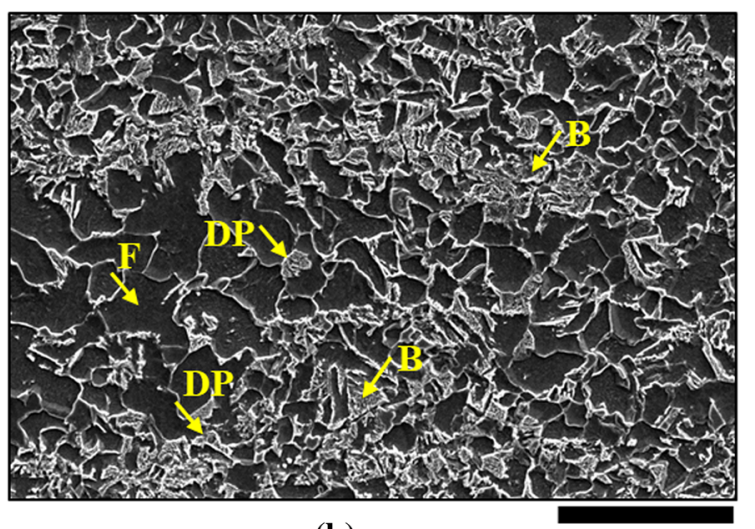

(b)

$20 \mu \mathrm{m}$

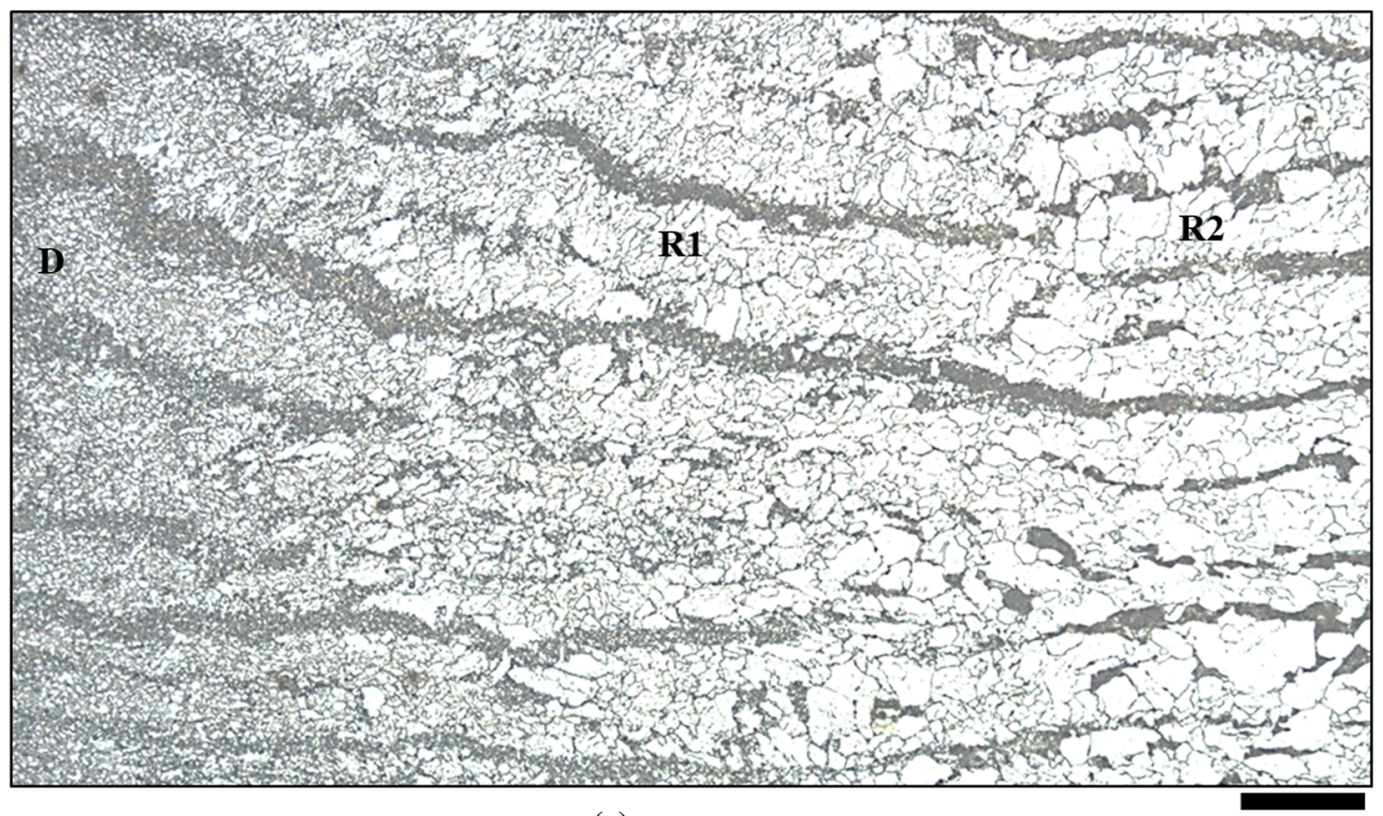

(c)

$50 \mu \mathrm{m}$

Fig. 2-(a) SEM micrograph of BM at area bb showing the banded ferrite-pearlite microstructure, (b) SEM secondary micrograph of the BM TMAZ interface at area b2 showing a mixture of bainite, $B$, ferrite, $F$, and possibly degenerate pearlite $(D P)$, and $(c)$ optical micrograph of BM/ HAZ boundary area close to bz. The locations of bb, b2, and bz are highlighted in Fig. 1.

on almost out of contrast dislocations within the laths at Q. Figure 7 following tilting experiments, shows well developed dynamically recrystallized grains, such as A, containing SIP. A CS appears within the circled area.

In Figure 8(a), the out-of-focus cell structures highlighted as CS were initially considered to be artifacts, but they appeared in contrast during tilting experiments in several foils. The curved grain boundaries which are pinned by particles, $\mathrm{P}$, are typical of a microstructure which is partially recrystallized, while the CS is of one that has undergone recovery. The SAED image from the cell microstructure of the same area presented in Figure 8(b) shows multiple spots, indicating low-angle boundaries present in Figure 8(a).

Figure 9(a) depicts groups of twins, separated by well-developed straight boundaries. The poor contrast is in part due to the large number of 'grains' in this micrograph. Figure 9(b) shows a dark field micrograph of twins, and particles formed on the twin boundaries. Figure 9(c) the SAED scan showing the 110 twinned reflections and the position of the (112) twinning plane in bec structures. 


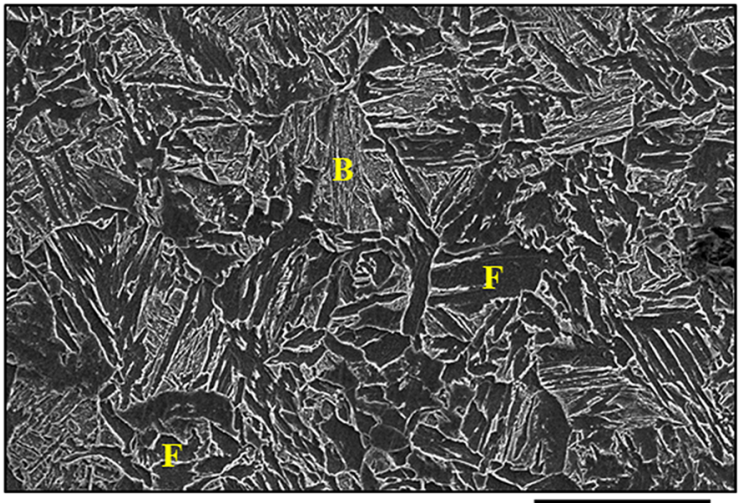

(a)

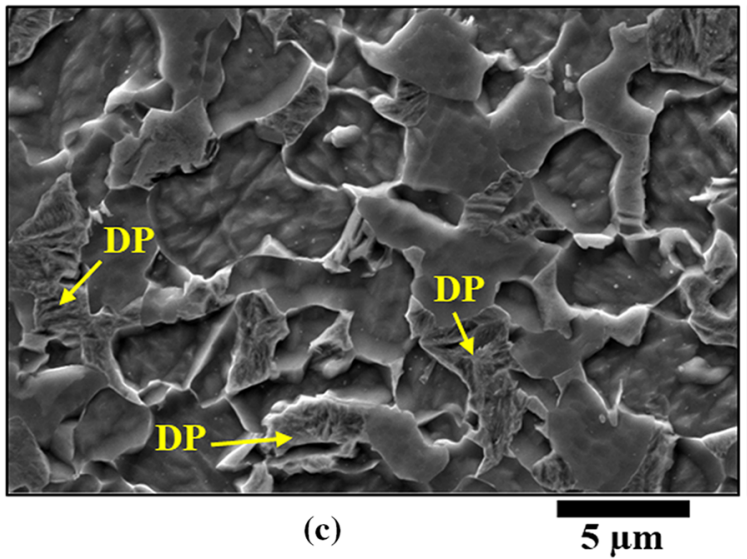

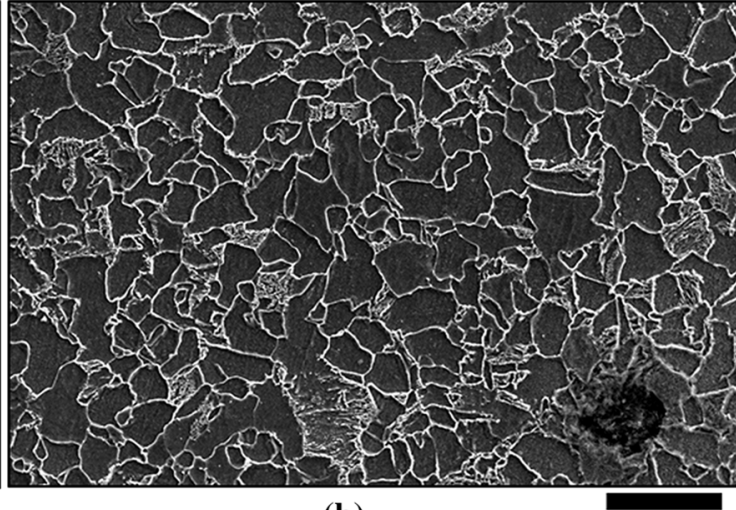

(b)

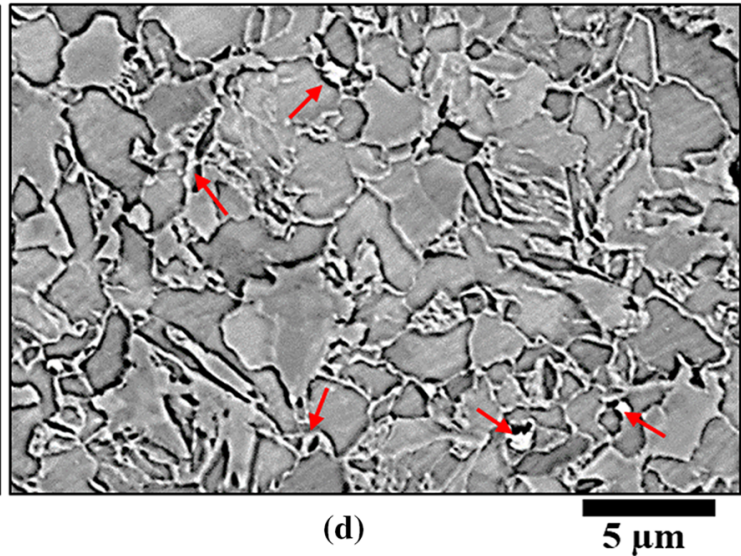

Fig. 3 - (a) SEM secondary electron (SE) micrograph of the SZ of the second weld pass at area b1, where $B$ and $F$ indicate bainite and ferrite, respectively, (b) SEM SE micrograph of the bottom of TMAZ of the second weld pass at b3, (c) SEM SE micrograph of deep-etched IZ at area zZ showing ferrite grains of 2 to $5 \mu \mathrm{m}$ in size, in which degenerated pearlite $(D P)$ grains are highlighted by arrows, and $(d)$ SEM backscattering (BS) micrograph of white etched M/A phase in area zz in the IZ, highlighted by arrows.

\section{B. Particle Analysis}

About 30 particles and inclusions in foils and on carbon replicas were analyzed by EDX in TEM, and in the metallographically prepared specimens by EDX in SEM. Most analyses were carried on the IZ regions to ascertain what carbides or carbonitrides were present and if cementite could be identified.

Figure 10(a) shows a TEM micrograph of an area in IZ containing a square shape particle on a grain boundary. In Figure 10(b), the Fe and $\mathrm{O}$ are possibly from the region surrounding the particle $\mathrm{P}$ in Figure 10(a) which is associated with a boundary $X-Y$, and $\mathrm{Cu}$ is from the support grid. The particle size is in the range of similar shaped particles observed in the BM and TMAZ, which invariably show a $\mathrm{Ti}$ peak in the corresponding EDX spectrum, as seen in Figure 10(b).

A selection of EDX spectra are shown in Figures 11(b) through (d). The background from the foils was not removed, so they all show strong Fe peaks. These spectra show that a very few particles contained vanadium, and a few showed strong titanium peaks. Many of those analyzed contained niobium, while several spectra showed no microalloying element-associated peaks. It is considered that all the particles labeled in Figure 11(a) were nucleated in the BM. They are in the correct size range to pin austenite grain boundaries, prior to the nucleation of bainite in the TMAZ, but too large to be involved in recovery.

Figure 12(a) from an area in BM, shows examples of the dual particle size seen in this steel, the larger, A $\sim 70 \mathrm{~nm}$, while the smaller ferrite was $\sim 5 \mathrm{~nm}$. SAED patterns from areas in the FSW foils, while often showing good matrix reflections, rarely showed many spots from particles. An exception is Figure 12(b) that is a SAED from particle A and the steel matrix, indexed following Gong et al. ${ }^{[21]}$ who interpreted the two patterns as linked by the Kurjumov-Sachs (K-S) orientation relationship. Figure 12(c) is a dark field SAED using the reflection indicated by $h k l_{\mathrm{p}}$ close to $00 \overline{2}_{\alpha}$ in Figure 12(d). The interplanar spacing calculated for $h k l_{\mathrm{p}}$ is $0.13 \mathrm{~nm}$ which is close to that of $\mathrm{NbC}$ (i.e., $0.0135 \mathrm{~nm}$ ), also based on the spectra showing significant $\mathrm{Nb}$ peaks in Figures 11(b) and (c), Nb is a strong possibility. ${ }^{[15]}$ This would suggest the small incoherent particles could be related to the steel matrix by the Baker-Nutting orientation relationship.

\section{Particle Pinning and Dynamic Recovery}

Figure 13 shows the classical sequence in the process of dynamic recovery in proximity of IZ leading to recrystallization, producing the equiaxed ferrite grains 


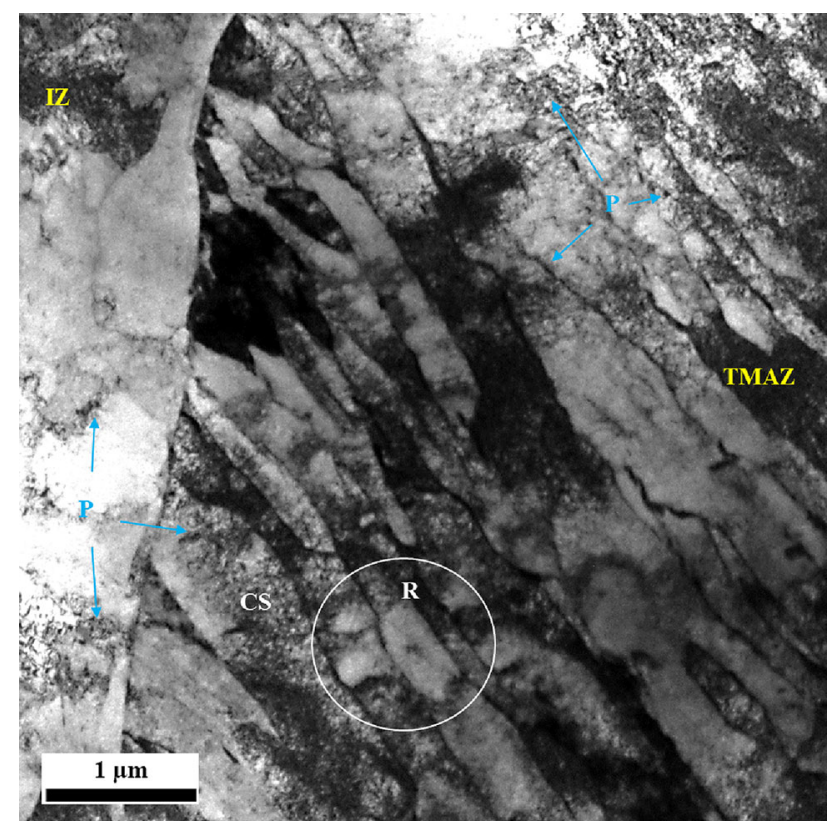

Fig. 4-TEM micrograph from area b3 in Fig. 1 showing the boundary region between TMAZ and IZ. Lath boundaries decorated with particles at $(P)$ and in the area outlined by the white circle at $R$, recrystallization occurred within the laths: others contain a cell structure $(C S)$.

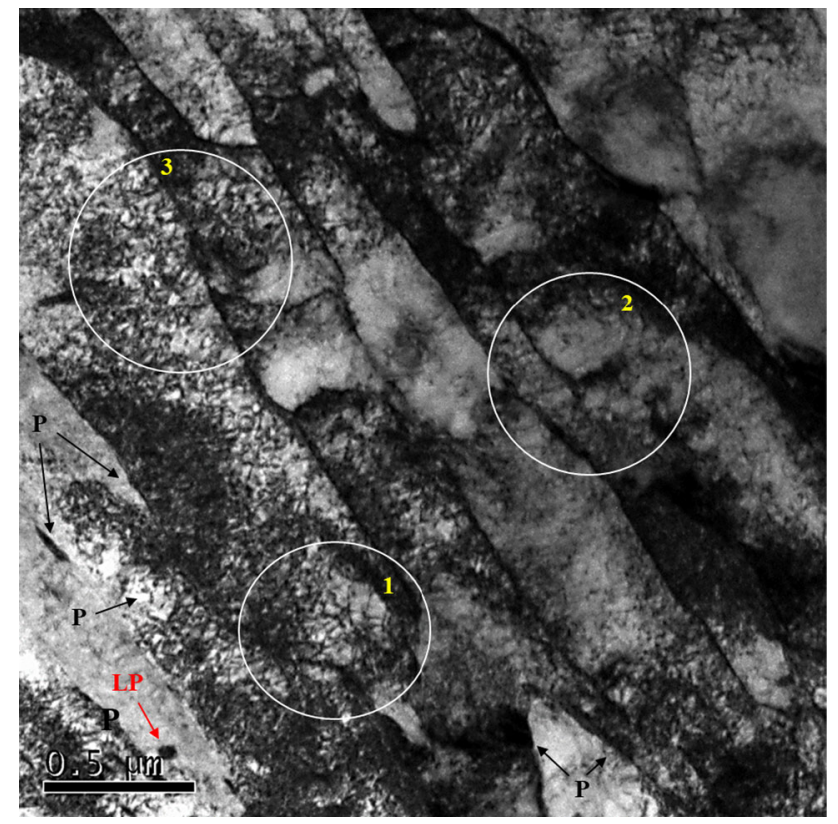

Fig. 5-TEM micrograph taken from area b1 in the SZ (i.e., top of TMAZ) of the second weld pass. A square-shaped particle located in a lath is arrowed at $L P$, while in the circled regions 1,2 , and 3, cells are present.

seen in Figures 3(b) through (d). It is proposed that the lath walls, $\mathrm{W}$, formed at a slightly earlier stage in the FSW process, is followed by dislocation networks evolving into CSs. This sequence would be repeated until the final deformation, which occurred just before the material was released on the RS (see Figure 1). At this point, the movement of freshly generated

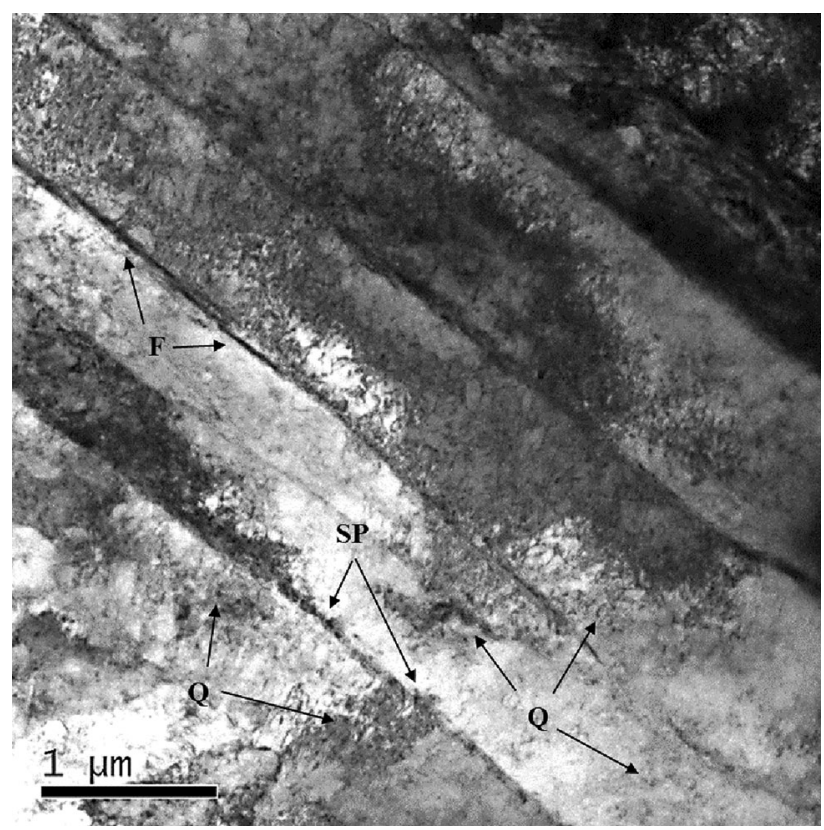

Fig. 6-TEM micrograph taken from area b3 in the bottom of TMAZ of the second weld pass close to the interface with the IZ, showing different stages of precipitate growth: at $F$ particles have formed into continuous films, whereas at $S P$ individual particles on lath boundaries are resolved. Within the laths at $Q$, SIP is observed on almost out of contrast dislocations.

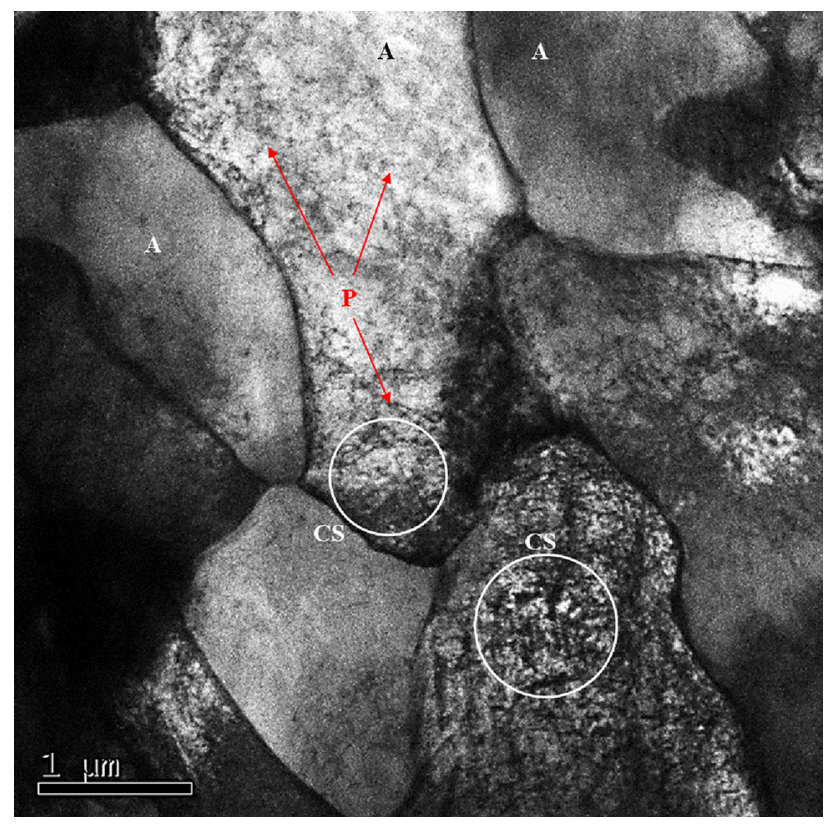

Fig. 7-A TEM micrograph taken from area $\mathrm{zZ}$ in the IZ. In dynamically recrystallized grains at areas highlighted by $A$, SIP is present, while within the circled areas named as $C S$, cell structures are observed.

dislocations is restricted by newly nucleated precipitates, being pinned in a classic Orowan manner. ${ }^{[22]}$ This latter position is frozen in Figure 13 at $\mathrm{P}$. Thompson, ${ }^{[23]}$ in discussing the development of substructure, reiterated the conventional understanding of cells being formed from tangles of dislocations at lower temperatures than 


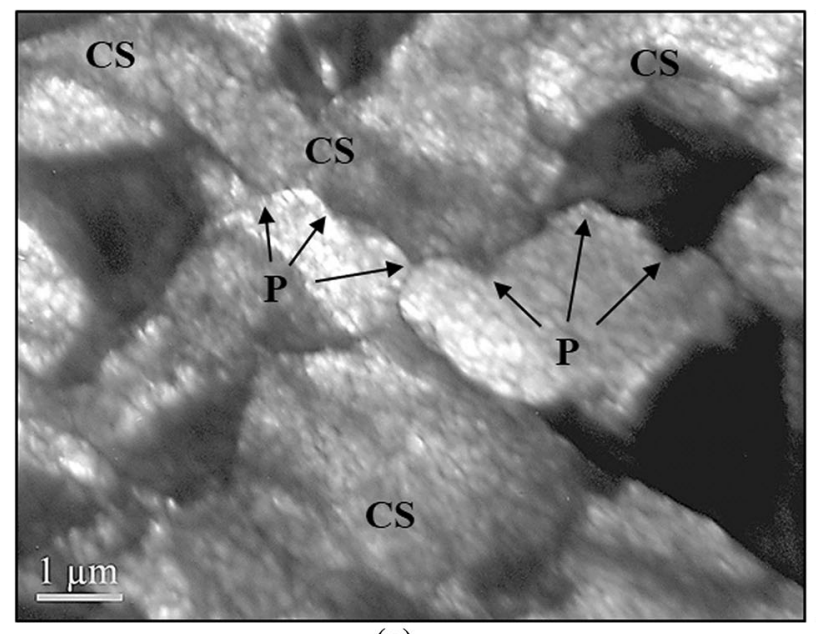

(a)

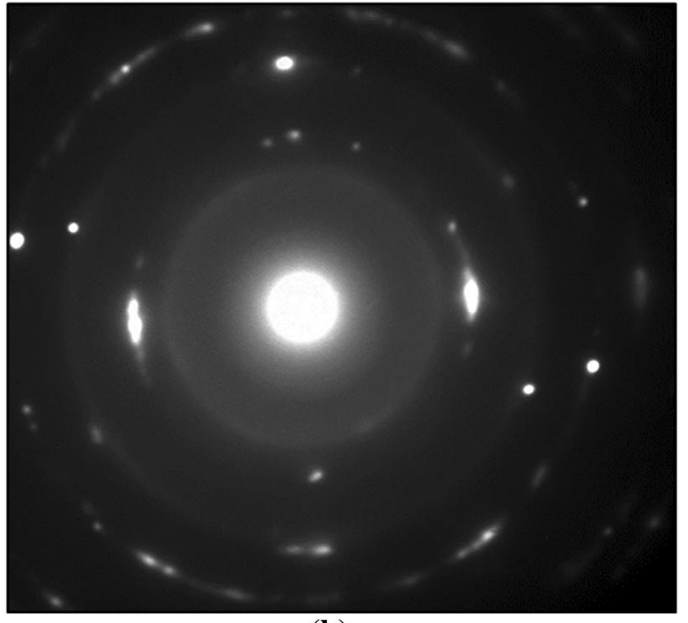

(b)

Fig. 8- (a) TEM micrograph of the IZ taken from area zz, showing curved grain boundaries pinned by particles, $P$, with out-of-focus cell structures, $C S$, and (b) SAED from the cell microstructure shown in (a).

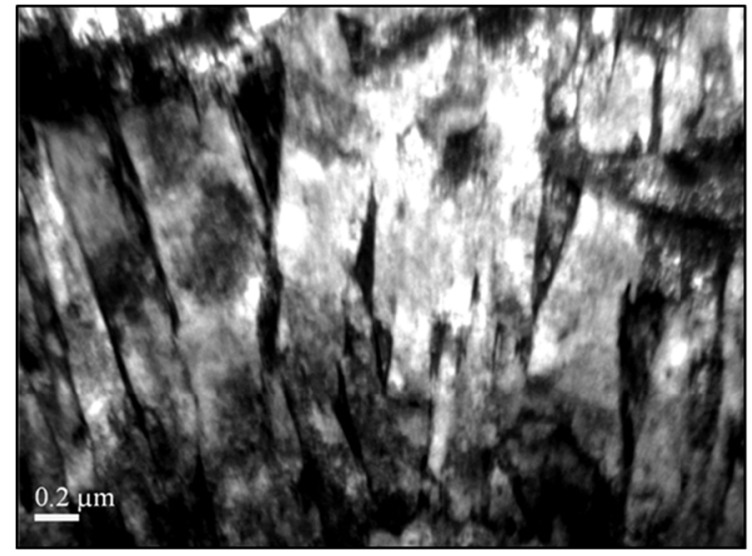

(a)

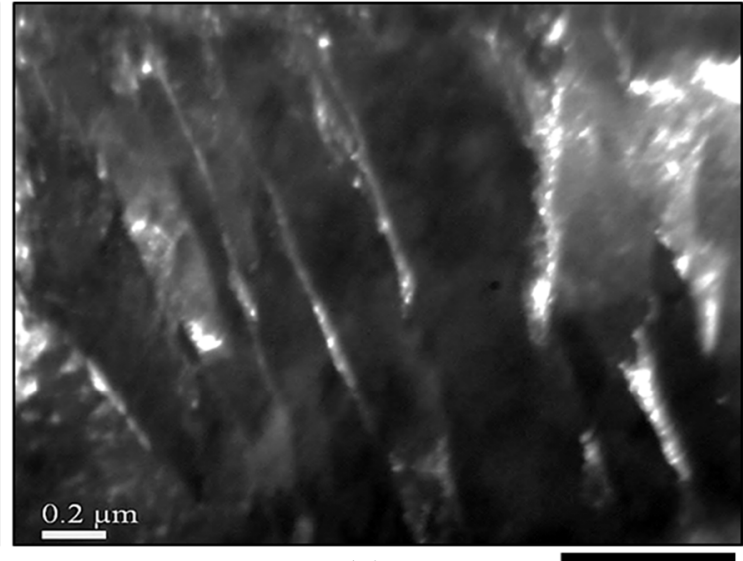

(b)

$20 \mu \mathrm{m}$

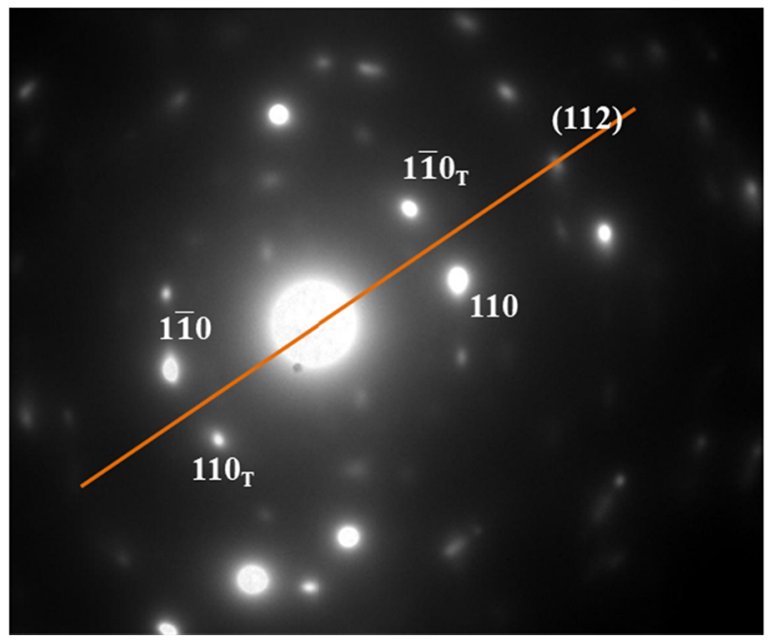

(c)

Fig. 9- (a) TEM micrograph of the area zz in the IZ, (b) TEM dark field micrograph of the zZ in the IZ, and (c) SAED scan of the same area as that of (a) and (b) showing the 110 twin reflection and the position of (112) twinning plane. 


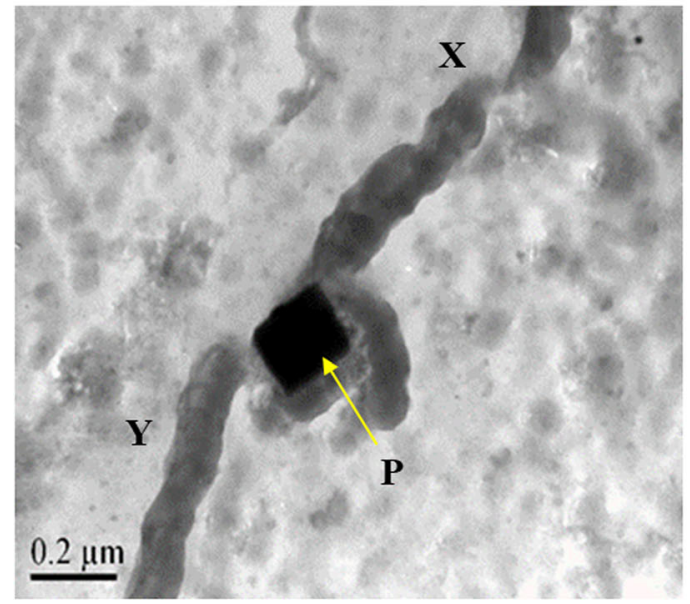

(a)

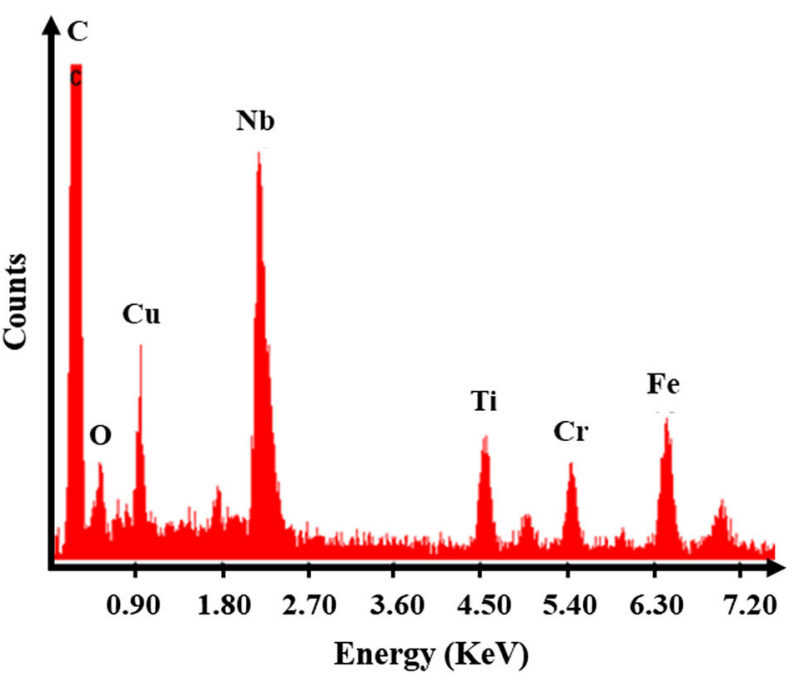

(b)

Fig. 10 - (a) TEM micrograph of the area $\mathrm{zZ}$ in the IZ from a carbon extraction replica, and $(b)$ EDX spectra taken from $\sim 200 \mathrm{~nm}$ particle $P$ in (a) consists of $\mathrm{Nb}, \mathrm{Ti}, \mathrm{Cr}$, square carbon, and probably $\mathrm{N}$.

subgrain are formed. Once the weld has been completed, many dislocations act as sites for precipitate nucleation, including those forming into walls, and those forming into cells within the walls. Fine precipitates are present in the BM, but the proliferation of particles observed in both the laths formed in the TMAZ and the equiaxed ferrite grains of the IZ, strongly suggest that the nanometre sized particles are newly precipitated during the FSW process.

\section{DISCUSSION}

\section{A. Effect of Temperature During FSW}

Earlier publications by Rahimi et al. ${ }^{[10]}$ and Baker and $\mathrm{McPherson}^{[15]}$ reporting study on the same FSW steel considered here, provided strong evidence that the peak temperature at the base of the pin during FSW was below $\mathrm{Ac}_{1}$. This was reflected in the microstructures of the IZ, which were fully ferritic, and also in the texture evolution that was simple shear, indicating the occurrence of deformation in a fully ferritic phase (i.e., below $\mathrm{Ac}_{1}$ ) during FSW. Padhy et al. ${ }^{[24]}$ summarized the effect of the process parameters which influence the maximum temperature reached during FSW as 'the rotation speed and traverse velocity govern the amount of frictional heat generated and subsequent plastic deformation and deformation heat. In general, a higher rotational speed produces a higher heat input, while a greater traverse speed reduces the heat input by shortening the time duration for the tool-work-piece interaction at a given point of action.' During FSW, the material undergoes intense plastic deformation at elevated temperatures resulting in significant grain refining. As described previously, ${ }^{[10]}$ in the overlap region of the IZ, ultrafine grains $(\sim 0.8 \mu \mathrm{m})$ seen Figures 3(b) and (c), have been quantified. No evidence of bainite was detected in the
IZ, supporting the view that during processing, the temperature in these zones was below the $\mathrm{Ac}_{1}$. The formation in these zones of fine and ultrafine grains ${ }^{[10,15]}$ may be due to the continuous dynamic recrystallization (CDRX) induced by substantial levels of shear deformation together with the heat generated by the FSW process. CDRX takes place by the progressive development of low-angle grain boundaries (LAGBs) within the grains subjected to severe plastic deformation, and their eventual conversion to high-angle grain boundaries (HAGBs) when they reach a critical misorientation angle. Reinforcing this view in the present investigation are micrographs in which the development of LAGBs and their transformation to HAGBs has been restricted by the new precipitation of carbides associated with dislocations, seen in Figures 6 and 13.

Arbegast $^{[25]}$ developed an empirical relationship (Eq. [1]) to estimate the maximum temperature $T$, reached during welding.

$$
T / T_{\mathrm{m}}=K\left(w^{2} / v \times 10^{4}\right)^{\alpha},
$$

where $T_{\mathrm{m}}$ is the melting point of the alloy, $w$ the tool rotation velocity, and $v$ the tool transverse velocity. $\alpha$ $(\sim 0.005)$ and $K(\sim 0.7)$ are constants. The estimated maximum temperature reached during welding for several investigations is given in Table IV.

The equation established by Arbegast, ${ }^{[25]}$ is dominated by the value taken for $T_{\mathrm{m}}$. As seen from the data in Table IV obtained using this expression, the estimated maximum temperature varies by only $21 \mathrm{~K}$ $\left(21{ }^{\circ} \mathrm{C}\right)$. The temperature at the bottom of the pin is expected to be considerably lower than the figures in Table IV. Lienert et al. ${ }^{[9]}$ measured the peak surface temperatures on the tool above the shoulder, which were close to $1273 \mathrm{~K}\left(1000{ }^{\circ} \mathrm{C}\right)$. However, based on extrapolation of the measured temperatures and the microstructural evidence, they considered that the 


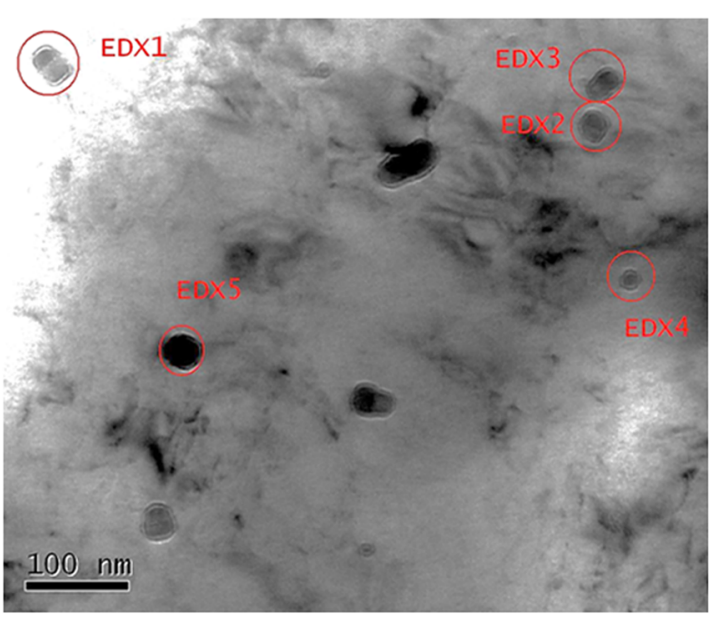

(a)

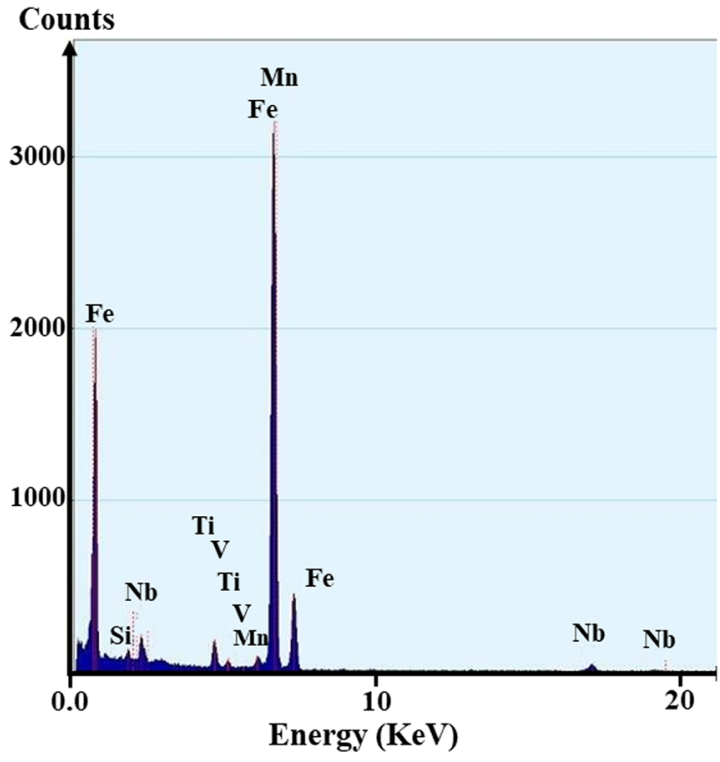

(c)

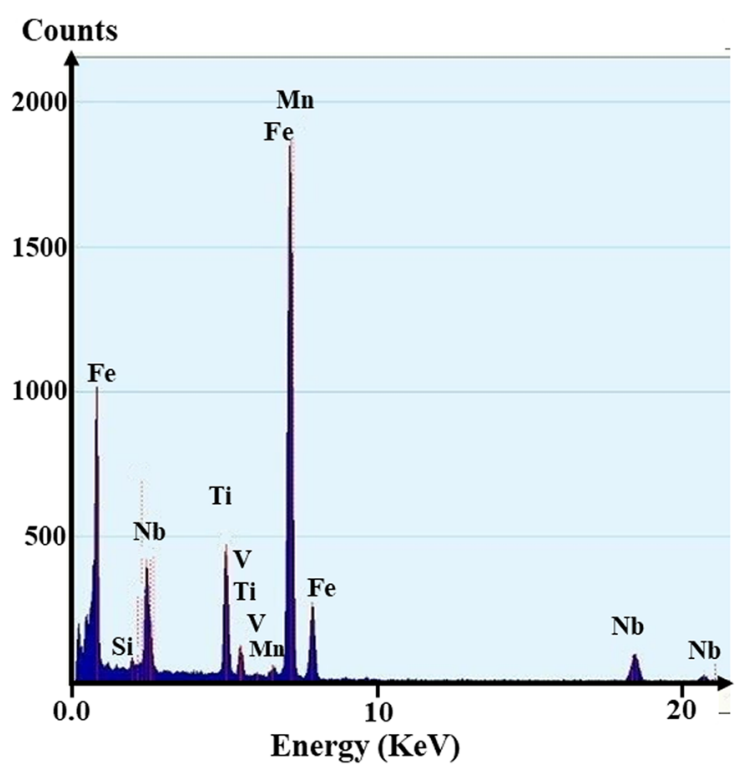

(b)

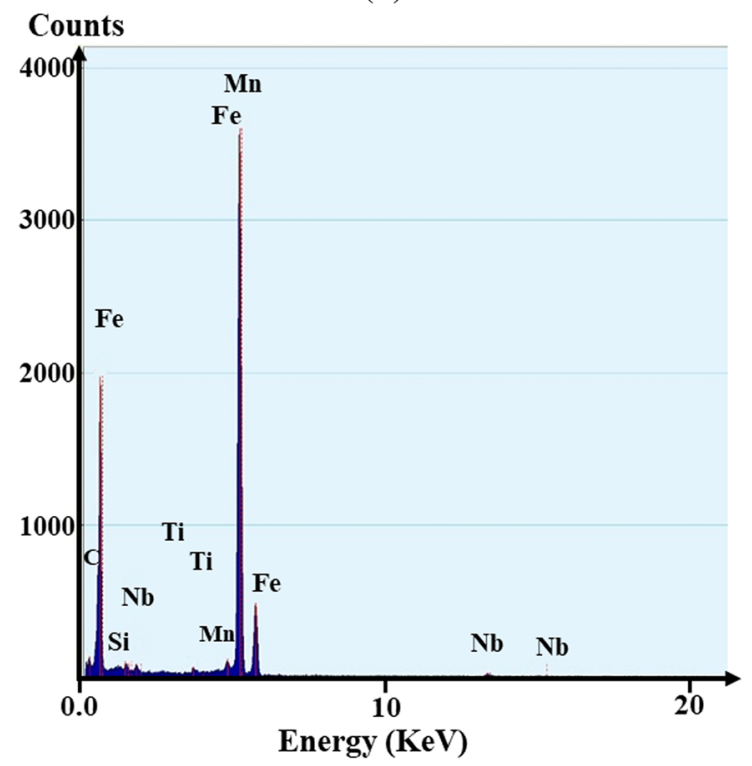

(d)

Fig. 11-(a) TEM micrograph of the zZ area in IZ indicating the particles analyzed by EDX, $(b),(c)$ and $(d)$ are EDX spectra for particles 1,3 and 4 in (a), respectively.

maximum temperatures of the $\mathrm{SZ}$ exceeded $1373 \mathrm{~K}$ $\left(1100{ }^{\circ} \mathrm{C}\right)$, and likely surpassed $1473 \mathrm{~K}\left(1200{ }^{\circ} \mathrm{C}\right)$.

The conditions used in the current study considered alongside those of Xue et al. ${ }^{[27]}$ support the assertion that the peak temperature at the base of the pin during FSW was below $\mathrm{Ac}_{1}$. In the current study the rotation velocity of the pin is at the low end of the range. ${ }^{[26,27]}$ While many papers consider that the tool rotation velocity and the tool traverse velocity are the main factors controlling microstructure which in turn influences the hardness variations, including the so-called hard zones, Wei and Nelson ${ }^{[28]}$ found that the postweld cooling rate also had a decisive influence.

\section{B. Effect of FSW on Pearlite in Steels}

Figures 3(c), 7 and 8 show the microstructure in the IZ following FSW, where normal pearlite is absent. Very few observations of cementite were unequivocally identified, due to difficulties in characterization using optical microscopy or EDX/SEM. Previous papers considering FSW of carbon steels have reported that the microstructure of the IZ is mainly bainitic, sometimes with a little DP. ${ }^{[16]}$ Depending on the FSW parameters, others recorded very fine lamellae pearlite colonies $^{[9]}$ or 'pearlite fractured into small pieces. ${ }^{\text {,29] }}$ This break-up of constituent particles was particularly evident in the FSW of $6 \mathrm{~mm}$ thick carbon steel investigated by Baillie 


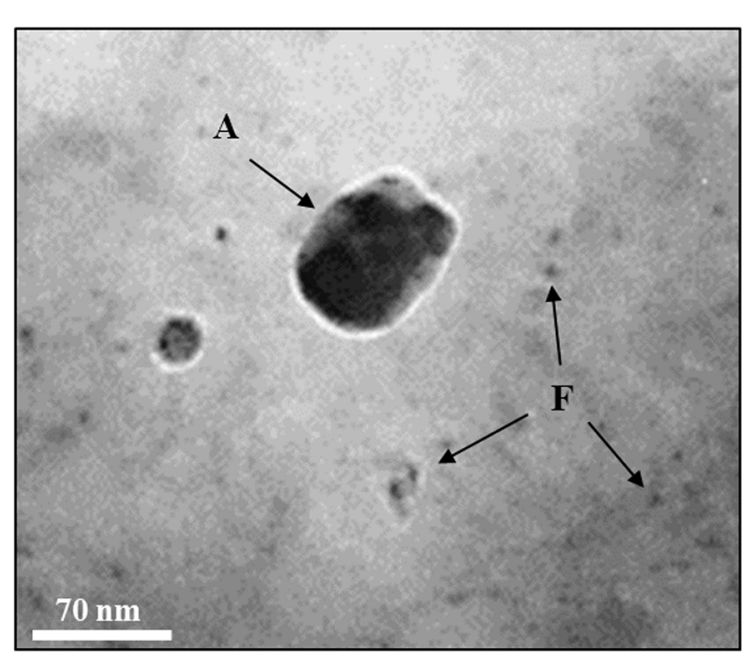

(a)

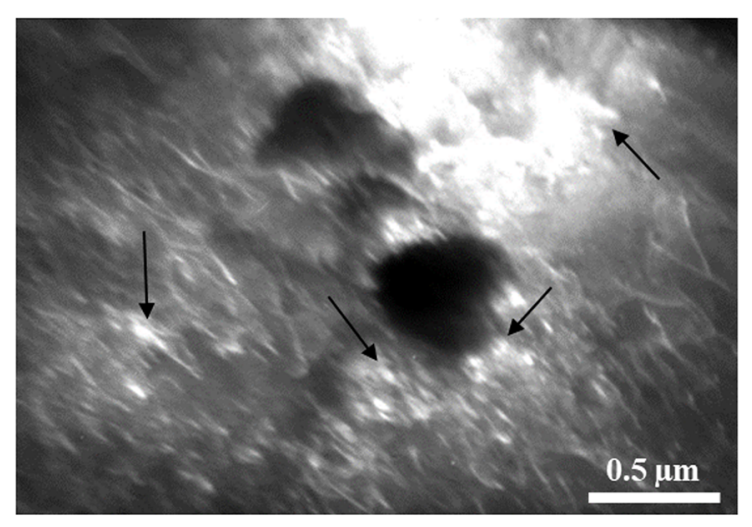

(c)

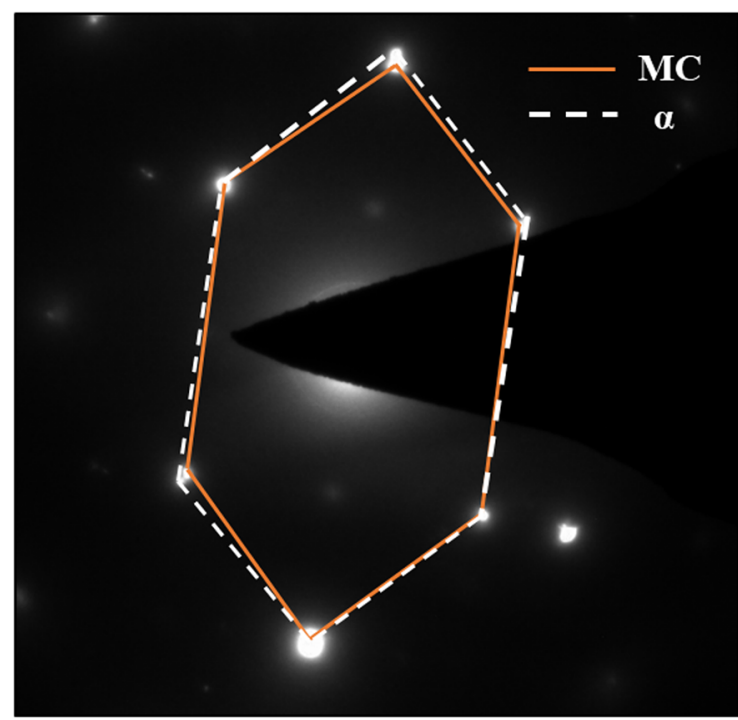

(b)

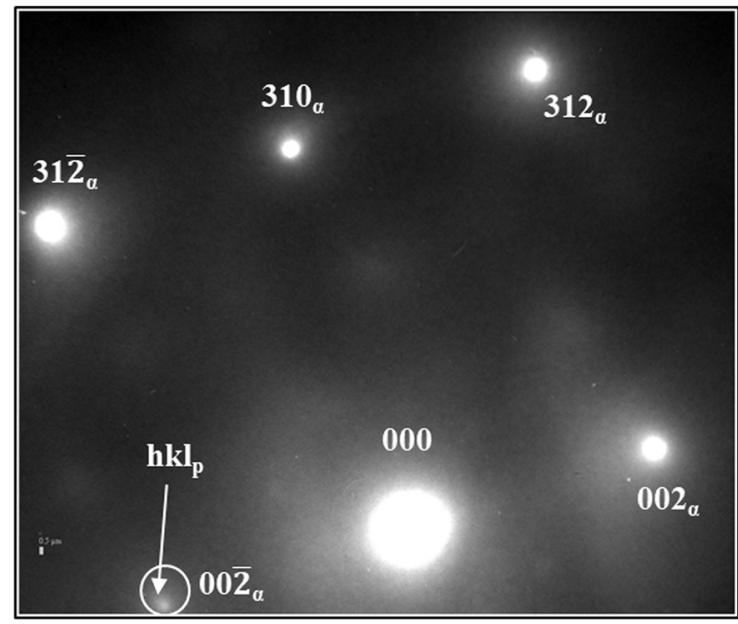

(d)

Fig. 12-(a) Two sizes of particles, $A(\sim 70 \mathrm{~nm})$ and $F(\sim 5 \mathrm{~nm})$ observed in BM around area bb in Fig. 1, $(b)$ SAED from particle $A$ shown in (a), (c) dark field TEM micrograph using the reflection indicated by $h k l_{\mathrm{p}}$ in $(d)$, and (d) SAED scan of a region shown in (c).

et al. ${ }^{[30]}$ and has also been noted in FSW of A1359-20 pet SiC MMC, which showed visible particle clusters and particle-free regions in the as-extruded composite. ${ }^{[31]}$ Both Shindo et al..$^{[31]}$ and Ma et al. ${ }^{[32]}$ reported that after FSW, the distribution of $\mathrm{SiC}$ particles was improved and the amount of finer $\mathrm{SiC}$ particles in the $\mathrm{NG}$ zone was significantly increased, due to intense plastic deformation and materials mixing. It is noted that $\mathrm{SiC}$ particles are at least twice as hard, 20 to $39 \mathrm{GPa}$, as cementite, $11.4 \mathrm{GPa}$.

There is therefore, evidence of particle redistribution in both steels and aluminum MMC's during FSW. Figure 2 show the ferrite-pearlite banded microstructure of the BM in the current study, which is converted predominantly to bainite in the TMAZ, but to polygonal ferrite in the IZ. Figure 2(c) at R1, shows clearly that in some areas, recrystallization of the ferrite bands in the BM close to the HAZ is well advanced. Whereas a substantial quantity of carbides is present on the lath boundaries of the bainite, pearlite is conspicuously absent in the IZ. Figure 2(a) shows 'classical eutectic pearlite' in the BM, whereas that indicated as DP in the IZ in Figure 3(c) has very few parallel lamellae, indicating an incipient form of pearlite, which is different from that normally described as DP. ${ }^{[15]}$ The pearlite morphology in Figure 3(c) could have arisen by reprecipitation, following the dissolution of cementite in the classic pearlite observed in Figure 2(a). It is therefore of interest to understand if there has been a redistribution of the carbon in the cementite of pearlite, and evidence that cementite has dissolved as a result of the FSW processing conditions used in the current study. With this aim in mind, a comparison was undertaken of other high strain processing methods showing evidence of cementite dissolution similar to that considered to occur during the present FSW.

A comparable low temperature deformation process to that of FSW is equal channel angular pressing/ extrusion producing ultrafine ferrite grains in carbon steels, ${ }^{[33]}$ also reported earlier in the current study. ${ }^{[10]}$ 


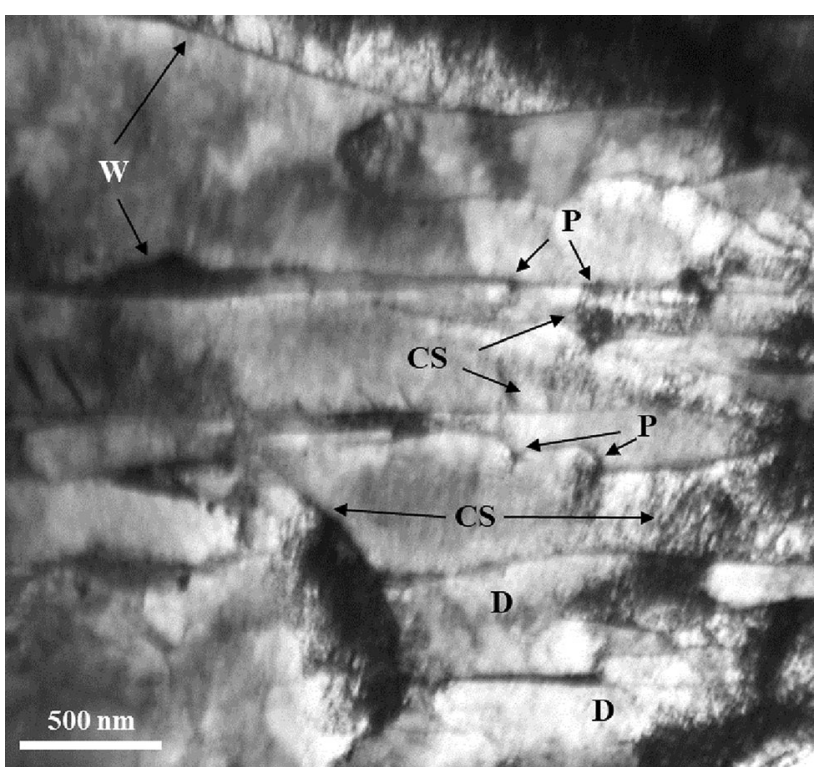

Fig. 13-TEM micrograph of TMAZ around area b3 in Fig. 1 close to the interface with IZ, showing recovery $(D)$ sequence in the evolution of recrystallized grains leading to the development of equiaxed ferrite grains. Lath walls, $W$, particles, $P$, pinning dislocations, and cell structures, $C S$ are denoted.

Ohmori et al. ${ }^{[34]}$ reported that after processing, pearlite was segmented and transformed into rows of spheroidized cementite particles. However, the possibility of cementite dissolution was not mentioned.

The stability of cementite and the distribution of carbon in ferrite following severely deformed high-carbon steel pearlitic wires has attracted much attention and been critically reviewed by Borchers and Kirchheim. ${ }^{[35]}$ Indirect proof of carbon dissolution in high-pressure torsion of a pearlitic steel was provided by Wetscher et al., ${ }^{[36]}$ who showed that at least a partial dissolution of the carbon from the cementite occurred. Hong et al. ${ }^{[37]}$ using atomic probe tomography (ATM) concluded that the carbon concentration in ferrite in drawn wire $(\varepsilon=4.22)$ was significantly higher, 0.6 to $0.83 \mathrm{wt}$ pct, than the equilibrium solubility of carbon in ferrite, $0.02 \mathrm{wt}$ pct at $600{ }^{\circ} \mathrm{C}$. Also, the importance of strain in determining the extent of cementite dissolution has been studied by ATM, ${ }^{[38]}$ and modeled by Nematollahi et al. ${ }^{[39]}$ It has been proposed by Gridnev and Garvrilyuk, ${ }^{[40]}$ that the heterogeneous dissolution of carbon in ferrite arises from its segregation to dislocations or dislocation pile-ups. They suggested that as the binding energy between carbon atoms and dislocations in ferrite $(0.8 \mathrm{eV})$ is nearly three times larger than that between carbon and iron in cementite $(0.27 \mathrm{eV})$, this makes it possible for dislocations to drag carbon out of cementite, forming Cottrell atmospheres. Ivanisenko et al. ${ }^{[11]}$ suggested that the process was more complex, involving three stages.

Others have taken a different approach to cementite dissolution. Bhadeshia ${ }^{[42]}$ considered the effect of carbon being segregated to the tetragonal interstices rather than those occupying the usually considered octahedral symmetry in the iron lattice, allowing a significantly greater carbon content to be held in solid solution in a nonequilibrium state.

Although both the steel compositions and the details of the methods of introducing severe strains in the above investigations differ from the case of FSW, they are considered here as providing a possible explanation for the apparent absence in the current study of significant quantities of pearlite or cementite in the IZ, an observation which has not been reported previously.

The effect of a supersaturation of carbon in solid solution in bainitic ferrite has recently been the subject of a critical assessment, ${ }^{[43]}$ while it has been suggested in microalloyed steels, for ferrite forming above the $\mathrm{Ac}_{3}$, a phenomena known as strain-induced transformation (SIT) or strain-induced dynamic transformation (SIDT) can take place. ${ }^{[4-47]}$ This is dependent on steel chemistry, deformation temperature, strain, and strain rate, which have been reviewed by Hutchinson and Komenda. ${ }^{[48]}$ Choi et al. ${ }^{[26]}$ observed that $\sim 2 \mu \mathrm{m}$ ferrite grains are obtained through dynamic transformation in the temperature range between $\mathrm{Ae}_{3}$ and $\mathrm{Ae}_{1}$. However, the microstructure following SIT/SIDT was due to the very rapid grain refinement and concurrent nucleation and random orientation distribution of ferrite grains due to the deformation.

Strong indications of the formation of cell-grain boundaries in ferrite were found by Li et al. ${ }^{[49]}$ In their case, most of carbon atoms in ferrite segregated to these boundaries. Based on these observations, they suggested that the dislocation density in the ferrite was probably the mechanism underlying cementite decomposition. In the present FSW, fewer dislocations within the cells (see Figures 4, 8, and 13), suggest that in these regions, cementite dissolution occurred during deformation and not post deformation.

Both Santos et al. ${ }^{[18]}$ and Fairchild et al. ${ }^{[50]}$ have previously reported the observation of the M/A phase based on the white constituent revealed by the LePera etch. ${ }^{[51]}$ However, neither was able to identify $\mathrm{M} / \mathrm{A}$ positively. The M/A phase is considered to be one of the constituents comprising 'local brittle zones.' Bhadeshia ${ }^{[52]}$ has calculated the carbon content of retained austenite to be the same as martensite for a low-carbon line pipe steel, at $0.66 \mathrm{wt}$ pct. Others have given lower carbon figures, in the range from 0.3 to 0.5 pct. These compare with the calculated $6.67 \mathrm{wt}$ pct carbon present in cementite. The procedure developed by Alé et al. ${ }^{[20]}$ was used in the current study which did reveal a white blocky shapes in Figure 3(d).

\section{Microtwins}

In the current study, groups of microtwins, seen in Figure 9(a) located in the bz-zz region of the weld, were only imaged occasionally, possibly due to the extensive presence of closely arrayed bend contours. Extensive tilting experiments were necessary to provide convincing diffraction evidence of microtwins.

The observation of twins in body-centered carbon steels has normally been associated with martensitic microstructures, and described as mechanical twinning or deformation twinning, produced under conditions of 
Table IV. Estimated Maximum Temperature Reached During Welding, Based on Eq. [1]

\begin{tabular}{lcccc}
\hline Alloys & $W(\mathrm{rpm})$ & $v\left(\mathrm{~mm} \min ^{-1}\right)$ & $T\left[\mathrm{~K}\left({ }^{\circ} \mathrm{C}\right)\right]$ & References \\
\hline Mild Steel & 300 & 100 & $1338(1065)$ & $1345(1072)$ \\
Mild Steel & 600 & 100 & $1346(1073)$ & 9 \\
Mild Steel & 300 & 25 & $1345(1072)$ & 9 \\
Mild Steel & 800 & 200 & $1333(1060)$ & 26 \\
Mild Steel & 180 & 125 & $1325(1052)$ & 15 \\
Mild Steel & 80 & 80 & 27 \\
\hline
\end{tabular}

high strain rates and low temperature. This was encountered in the present FSW study. Twinning is a fault in planar stacking, and among the first to record evidence of nonmartensitic twinning in iron were Takeyama and Koepel $^{[53]}$ in their study of zone-melted iron. Fine twins, so-called microtwins, were characterized in laboratory controlled-rolled vanadium $\mathrm{M} / \mathrm{A}$ steels, and described as transformation twins. ${ }^{[54,55]}$ The possibility of vanadium lowering the stacking fault energy of iron was one tentative suggestion, and to the best of knowledge, twins have not been reported in single alloyed niobium, titanium or zirconium microalloyed steels. Furthermore, the importance of nitrogen in the formation of nanotwins in the bainitic microstructure of a carbonitrided low-alloy steel has been reported by Van Landeghem et al. ${ }^{[56]}$ Recently, transformation microtwins have been identified in the weld HAZ of $\mathrm{M} / \mathrm{A}$ steels in which the total of $\mathrm{Ti}+\mathrm{Nb}+\mathrm{V}$ was $\sim 0.2 \mathrm{wt}^{[57]}$ The presence of twins, observed mainly in very small regions of the CGHAZ, was considered to arise as a means of relieving high thermal, solidification-induced, and transformation-induced stresses. In Figure 9(b), precipitates on twin boundaries in bright contrast are almost certainly due to imaging using a $200_{\mathrm{VCN}}$ reflection which is very close to $110_{\text {ferrite }}($ Figure $9(\mathrm{c})) .^{[58]}$

\section{Recrystallization, Recovery, and Precipitation}

Understanding the development of microstructure in FSW M/A steels is complicated by the dynamic nature of the process, and that unlike most other thermomechanical deformation processes, the sequence in the evolution of microstructure can only be surmised after the completion of welding. The current study differs from others which reported FSW of carbon steels due to the contention that the ferrite observed in the IZ had not transformed from austenite during the welding. This was because the $\mathrm{Ac}_{1}$ temperature had not been exceeding during welding. The absence of bainite in the IZ supports this view. Also, no interphase precipitation, which is associated with the $\gamma \rightarrow \alpha$ phase transformation, was observed following FSW, as is commonly reported in hot-rolled $\mathrm{M} / \mathrm{A}$ steels.

The present investigation has confirmed earlier study ${ }^{[14]}$ that during FSW, the original M/A grain structure of the BM was almost completely eliminated and replaced by very fine equiaxed ferrite grain structures in TMAZ and the IZ. It is also believed that the present FSW process resulted in cementite of the BM dissolving. However, it has been found that what is

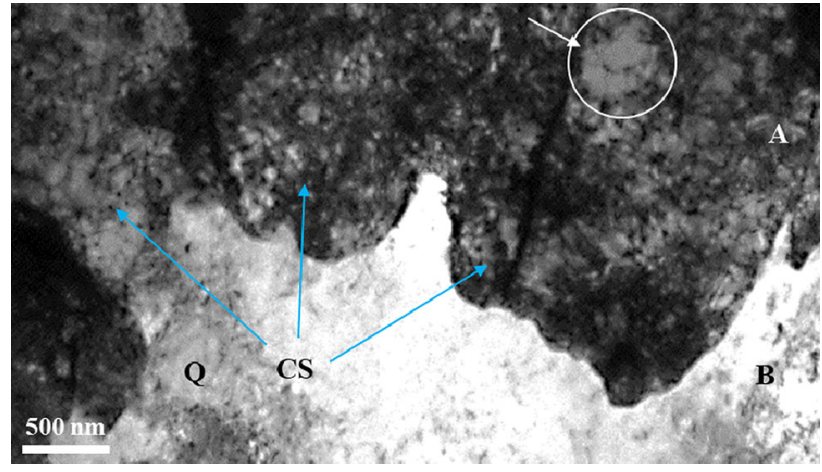

Fig. 14-TEM micrograph of area $\mathrm{zZ}$ in Fig. 1 located in IZ showing evidence of two recrystallization processes of strain-induced boundary migration (SIGBM) with classic bulging of HAGB, and continuous dynamic recrystallization (CDRX) forming cells.

thought to be some of the original TiN carbides of the $\mathrm{BM}$ are still in evidence in the TMAZ (Figure 10(a)). Additionally, it is considered that in the overlap region of the IZ, the processing of the second weld pass controlled the final microstructure in this region.

In parts of the TMAZ, as in Figures 4 and 5, ferrite laths of bainite present following transformation from austenite, exhibit copious fine particles nucleated on dislocations indicated by $\mathrm{P}$, described as SIP. Some particles may nucleate in the two-phase region as soon as the welding commences. In places, dislocations may be torn from their precipitates during processing as the build-up in strain increases, while dislocations formed at the end of the strain period, which is after $\sim 3$ revs of the tool, may be relatively free from precipitates. In other areas auto tempering could result in SIP. Figure 6 from region b3, shows bainite laths packed with cells, whilst in other laths at $\mathrm{Q}$, there are dislocations on which particles have nucleated. This suggests that the cells formed due to strain introduced earlier in the FSW process, while the pinned dislocations were introduced at a late stage in the process on the RS of the weld, and were frozen due to the relief of strain, as the welded steel moved on.

Similar observations of extensive SIP in some regions of the IZ are observed which contain many fine particles (Figures 7 and 13), while in adjacent regions, dislocation walls forming cell-like structures appear to have developed from mobile precipitate-free dislocations. Figures 8,13 and 14 suggest that recovery is continuous in nature, but has not been completed. 
Subgrain structures with low-angle boundaries (LAGBs) separating cells are formed during deformation in materials with high stacking fault energies, such as microalloyed steels. Due to efficient dynamic recovery, LAGB evolve into HAGBs upon reaching a critical misorientation, a process now known as CDRX. ${ }^{[59,60]}$

The subgrains and cells in Figures 7, 8 and 13 have a similar appearance to those found in $7050 \mathrm{Al}$ alloys ${ }^{[61]}$ and described earlier by Thompson. ${ }^{[23]}$ Cells have been observed to develop in both $\mathrm{Al}$ alloys ${ }^{[61]}$ and $\mathrm{M} / \mathrm{A}$ steels ${ }^{[15]}$ under FSW conditions, suggesting the occurrence of CDRX.

Beck and Sperry ${ }^{[62]}$ proposed that in their study involving high-purity aluminum, strain-induced grain boundary migration (SIGBM) was the principal mechanism of DRX. In the partially completed process captured in Figure 14, DRX has involved the irregular motion of an irregular jagged front consisting of curved sections of grain A, bulging into a grain bainite, containing a high dislocation density, which is mainly out of contrast. A HAGB separates the two grains. In grain $\mathrm{A}$, the dislocations have formed cells, denoted by arrows from CS, and in some places, such as the ringed region, the cells have grown to several times the size of those denoted by CS, at a distance behind the advancing interface. It is suggested that during the few revolutions of the pin in contact with the BM, that SIGBM occurred initially developing a small ferrite grains, which were subsequently subject to CDRX.

Figure 15 from a similar region of the IZ to Figure 14, captures a microstructure showing several stages of CDRX, commencing with a high density of dislocations in IZ. It is speculated that the microstructure depicts a situation after the steel had exited from the pin, on the RS of the weld, in the final stage of welding. The original ferrite grain size of the BM has already been refined by the CDRX and the continuous

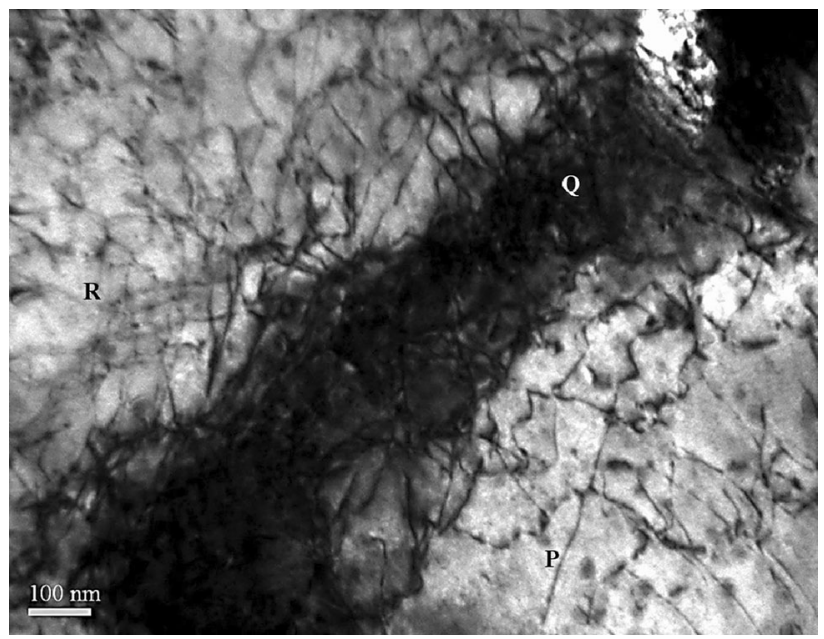

Fig. 15-TEM micrograph of area $\mathrm{zZ}$ in Fig. 1 located in IZ showing the dislocation tangles on each side of a bend contour, which are the first stage in the development of subgrains, and at lower temperatures, cells at $R$. Many of the dislocations are associated with particles, as at $P$. They were probably pinned initially, and while being stationary, became nucleation sties for other particles. deformation has resulted in new dislocations being generated. With the relaxation of stress, there is insufficient energy for initiating further recovery, so catching at $\mathrm{R}$, cell formation at an early stage. On the other side of the bent contour, at $\mathrm{P}$, precipitates growing on dislocations (SIP) are present, hindering recovery. At Q, the jagged boundary of a grain containing cells has appeared, an evidence of the classic nucleation forming a grain separated from the surroundings by a high-angle boundary. Doherty et al.$^{[63]}$ have reiterated the view that the nucleation of SIP has the ability to prevent or suspend both static and DRX, but that continuing deformation also leads to coarsening of the 'old' precipitates, so that 'fresh' ones are generally considered to be required for the prevention of recrystallization. In FSW of M/A steels, SIP is most likely to occur on stationary dislocations caused by interaction with others in the forest, or with those moving with velocities less than the rate of pipe diffusion of the transition metals, niobium and vanadium, along dislocations. $\mathrm{NbC}$ and $(\mathrm{Nb}, \mathrm{V}) \mathrm{C}$ precipitates are the most likely precipitates to pin the dislocations.

Pinning of subgrain and HAGBs has been shown to occur when the average particle size is in the size range 10 to $300 \mathrm{~nm}$, and the particle volume fraction, $f<0.01$. ${ }^{[64]}$

The nucleation of particles on dislocations in the $\mathrm{BM}^{[15]}$ and in both bainite in the TMAZ and ferrite in the IZ is a feature of the microstructure in the current FSW of M/A steels. EDX spectra in Figure 11 are from the particles which are more than an order of magnitude larger than the SIP seen in Figures 7, 13, and 15. These SIPs were too small to be analyzed on the equipment available for the current study and appear similar to those found in the controlled, rolled M/A steel finish rolled at $873 \mathrm{~K}\left(600{ }^{\circ} \mathrm{C}\right)$, when recovery was suppressed. ${ }^{[65]}$ Under hot-rolling conditions of $\mathrm{M} / \mathrm{A}$ steels, SIP of carbides, nitrides, and carbonitrides in austenite occur exclusively on dislocations, and dislocation substructures formed during deformation. ${ }^{[6-69]}$ Several models relevant to this situation have been published. ${ }^{[70,71]}$ These are apposite for precipitation in the BM, which would be subjected to SIP in austenite, and are most probably those observed in Figure 11(a). Precipitates noted in Figures 7, 13, and 15 in the IZ, which are considered to have remained below the $\mathrm{Ac}_{1}$ temperature during FSW, have undergone SIP in the ferrite phase, which has received much less attention in the literature. Shanmugam et al. ${ }^{[67]}$ observed fine-scale $(\sim 5$ to $10 \mathrm{~nm})$ precipitation in the ferrite matrix of both $\mathrm{V}$ - and Nb-containing steels. Analysis of SAED patterns revealed that these fine precipitates were MC type of niobium and vanadium carbides, in the respective steels, which obeyed the Baker-Nutting orientation relationship with the ferrite matrix, whereas the $\mathrm{K}-\mathrm{S}$ orientation relationship held for the carbides formed in austenite. ${ }^{[72]}$ This approach was also used to distinguish SIP of (Mo, $\mathrm{Nb}) \mathrm{C}$ in ferrite, ${ }^{[73]}$ and to follow random SIP of V (C, $\mathrm{N}$ ) in ferrite. ${ }^{[74]}$ However, as shown by the elegant TEM/ SAED of Gong et al., ${ }^{[21]}$ care must be taken when using this method to characterize SIP in ferrite. The development of SIP in bainite, which is appropriate for the 
Table V. Estimated Limiting Sizes for Coherency of Platelet Carbides and Nitrides Found in Ferrite in Microalloyed Steels

\begin{tabular}{|c|c|c|c|c|c|}
\hline \multirow[b]{2}{*}{ Carbides and Nitrides } & \multirow[b]{2}{*}{ Lattice Parameter 'a' (nm) } & \multicolumn{2}{|c|}{ Misfits } & \multicolumn{2}{|c|}{ Limiting Sizes for Coherency } \\
\hline & & $\varepsilon_{1}$ & $\varepsilon_{2}$ & $x_{1}(\mathrm{~nm})$ & $x_{2}(\mathrm{~nm})$ \\
\hline $\mathrm{NbC}$ & 0.447 & 0.065 & 0.292 & 1.54 & 0.34 \\
\hline $\mathrm{NbN}$ & 0.4388 & 0.053 & 0.279 & 1.89 & 0.36 \\
\hline $\mathrm{TiC}$ & 0.43285 & 0.043 & 0.27 & 2.33 & 0.37 \\
\hline TiN & 0.4254 & 0.062 & 0.326 & 1.45 & 0.31 \\
\hline $\mathrm{VC}$ & 0.416 & 0.017 & 0.245 & 5.85 & 0.41 \\
\hline $\mathrm{VN}$ & 0.409 to 0.417 & 0.006 & 0.234 & 8.38 & 0.43 \\
\hline
\end{tabular}

present research, Figure 6, has been considered by Zajac. ${ }^{[75]} \mathrm{He}$ has observed abundant precipitation of nanoscale microalloy nitrides and carbides in the dislocated bainitic ferrite matrix, over a broad temperature range, down to $573 \mathrm{~K}\left(300{ }^{\circ} \mathrm{C}\right)$, but comments on the difficulties in investigating these microastructures with conventional techniques.

The slight increase in microhardness recorded in the IZ compared with that of the $\mathrm{BM}^{[10,15]}$ is associated with the finer ferrite grain size and SIP, the latter being regarded as heterogeneous incoherent precipitation nucleated on dislocations. Precipitation hardening by coherent precipitates has been considered in several reviews. ${ }^{[76-78]}$ However, this subject has received little attention in strained microalloyed steels, due to difficulties in observing such fine precipitates. Shearing of coherent precipitates by dislocations may renders them unstable due to reducing their size below that of a critical embryo. ${ }^{[79]}$ This results in their dissolution, which is well established for aluminum alloys. ${ }^{[79,80]}$ Gong et al. ${ }^{[21]}$ considered particles of $\mathrm{NbC}$ in an $\mathrm{M} / \mathrm{A}$ steel to be coherent, while others ${ }^{[58,81]}$ showed streaking of matrix spots in SAED patterns from VC precipitates, consistent with particle coherency. The latter also observed coherency particle strain field contrast in the same alloys, similar to that published by Sass et al. ${ }^{[82]}$ Estimates of the size at which coherency of transition metal carbides and nitrides in $\mathrm{M} / \mathrm{A}$ steels is lost, Table $\mathrm{V}$, show that this increases from titanium nitride to vanadium nitride. ${ }^{83]}$

There is therefore a possibility that in addition to the fine incoherent SIP observed in the BM, in Figure 12(a), some of the other precipitates, not resolved, were coherent. During the FSW process, these coherent precipitates dissolved then reprecipitating through SIP, in both bainite laths and IZ, resulting in the precipitation observed in Figures 7, 12(a), 13 and 15. This process would be enhanced through dissolution of cementite mentioned above, with the possibility that some of the SIP is cementite.

The precipitation of transition metal carbides, nitrides, and carbonitrides depends primarily on the solubility product of the precipitating species at a given temperature. It should be noted that the solubility equations discussed in many publications, for example References 83 through 85 , were determined under, or close to equilibrium conditions. The observations of copious SIP in ferrite in both the laths in the TMAZ,
(Figure 6) and small $(\sim 0.8 \mu \mathrm{m})$ equiaxed ferrite grains in the IZ (Figure 3(c)), requires both carbon and the microalloying elements to be solution at some stage during the FSW process. Carbide solubilities in ferrite are considerably lower than in austenite. For example, at a temperature of $1000 \mathrm{~K}\left(727^{\circ} \mathrm{C}\right)$, equilibrium alloy carbide solubilities in ferrite are between about $1 / 6$ and $1 /$ 30 of those in austenite. ${ }^{[86]}$ Therefore, under the nonequilibrium conditions of FSW, more SIP might be expected which would contribute to the higher hardness found in the IZ compared with the BM or TMAZ. ${ }^{[10,15]}$

\section{CONCLUSIONS}

A study has been undertaken using analytical SEM and TEM, to understand the evolution of microstructure resulting from double-sided FSW of a 14.5-mm-thick shipbuilding grade EH46, niobium-vanadium microalloyed steel. It had previously been established that the TMAZ region was processed in the two-phase $\gamma+\alpha$ field, while the overlapped IZ was welded below $\mathrm{Ac}_{1}$ temperature.

During the FSW, it was confirmed that the original $\mathrm{M} / \mathrm{A}$ grain structure of the BM was almost completely eliminated, being replaced in the TMAZ by a mainly upper bainitic lath structure. Some $\mathrm{M} / \mathrm{A}$ phase was observed by $\mathrm{OM}$ in suitably etched samples. Individual fine particles were seen on lath boundaries in some places, but in others, the precipitates had grown into thin films, typical of upper bainite. Many laths contained cells, indicating that CDRX had taken place during processing. In the same sample, other laths exhibited high dislocation densities with many dislocations showing SIP. There was some evidence of twinning in the TMAZ region. The possibility of coherent carbonitrides being involved in contributing to the increase in hardness in the IZ is considered.

Submicron, equiaxed ferrite grains were observed in the IZ, which due to the small overlap of 2 to $2.5 \mathrm{~mm}$ thickness, was not separated into material undergoing one or two welds. Very little DP or cementite was characterized in the IZ. This led to the suggestion that, as identified in similar processes involving severe strains, dissolution of cementite very probably occurred. However, to the best of our knowledge, this is the first report of cementite dissolution occurring due to FSW of an $\mathrm{M} / \mathrm{A}$ steel. 
Cells, $~ 100 \mathrm{~nm}$ size, within the HAGB grains of IZ were seen. In other grains, SIP was present. As observed in the current study, the arrangement of cells within equiaxed grains spread throughout the IZ, strongly supporting the opinion that CDRX is a major recrystallization process in this FSW investigation.

\section{ACKNOWLEDGMENTS}

K. He and B. Wei acknowledge the financial support of National Natural Science Foundation of China (No. 51271202); and G. Johnson and J. Kelly are thanked for their technical support. The authors would like to acknowledge the support provided by the Advanced Forming Research Centre (AFRC), University of Strathclyde, which receives partial financial support from the UK's High Value Manufacturing CATAPULT.

\section{OPEN ACCESS}

This article is distributed under the terms of the Creative Commons Attribution 4.0 International License (http://creativecommons.org/licenses/by/4.0/), which permits unrestricted use, distribution, and reproduction in any medium, provided you give appropriate credit to the original author(s) and the source, provide a link to the Creative Commons license, and indicate if changes were made.

\section{REFERENCES}

1. G. Cam: Int. Met. Rev., 2011, vol. 56, pp. 1-48.

2. W.M. Thomas and C.J. Dawes: Weld, 1996, vol. 75, pp. 41-45.

3. S. Mironov, Y.S. Sato, H. Kokawa, H. Inoue, and S. Tsuge: Acta Mater., 2011, vol. 59, pp. 5472-81.

4. Y.S. Sato, T.W. Nelson, and C.J. Sterling: Acta Mater., 2005, vol. 53 , pp. $637-45$.

5. S. Rahimi, T.N. Konkova, I. Violatos, and T.N. Baker: Metall. Mater. Trans. A, 2019, vol. 50A, pp. 664-87.

6. J. Young, D.P. Field, and T.W. Nelson: Metall. Mater. Trans. A, 2013, vol. 44A, pp. 3167-75.

7. M. Gosh, K. Kumar, and R.S. Mishra: Scripta Mater., 2010, vol. 63, pp. 851-54.

8. P.J. Konol, J.A. Mathers, R. Johnson, and J.R. Pickens: J. Ship Prod., 2003, vol. 19, pp. 159-64.

9. T.J. Lienert, W.L. Stellwag, B.B. Grimmett, and R.W. Warke: Weld. J. Res. Suppl., 2003, vol. 82, pp. 1-9.

10. S. Rahimi, B.P. Wynne, and T.N. Baker: Metall. Mater. Trans. A, 2017, vol. 48A, pp. 362-78.

11. D. Easton, J. Wood, S. Rahimi, A. Galloway, Y. Zhang, and C. Hardie: IEEE Trans. Plasma Sci., 2016, vol. 44, pp. 1625-30.

12. G. Benghalia, S. Rahimi, J. Wood, H. Coules, and S. Paddea: Mater. Perform. Charact., 2018, vol. 7, pp. 606-29.

13. W. Rae, Z. Lomas, M. Jackson, and S. Rahimi: Mater. Charact., 2017, vol. 132, pp. 10-19.

14. S.J. Barnes, A. Steuwer, S. Mahawish, R. Johnson, and P.J. Withers: Mater. Sci. Eng. A, 2008, vol. 492, pp. 35-44.

15. T.N. Baker and N.A. McPherson: Mater. Sci. Technol., 2017, vol. 33, pp. 234-43.

16. P.L. Threadgill: Sci. Technol. Weld. Join., 2007, vol. 12, pp. $357-60$.
17. A. Ozekcin, H.W. Jin, J.Y. Koo, N.V. Bangaru, R. Ayer, G. Vaugn, R. Steel, and S. Packer: Int. J. Offshore Polar Eng., 2004, vol. 14 , pp. $284-88$.

18. T.F.A. Santos, T.F.C. Hermenegildo, C.R.M. Afonso, R.R. Marinho, M.T.P. Paes, and A.J. Ramirez: Eng. Fract. Mech., 2010, vol. 77, pp. 2937-45

19. P. Baillie, S.W. Campbell, A.M. Galloway, S.R. Cater, and N.A. McPherson: Int. J. Chem. Nucl. Metall. Mater. Eng., 2014, vol. 8, pp. 651-55.

20. R.M. Alé, J.M.A. Rebello, and J. Charlier: Mater. Charact., 1996, vol. 37, pp. 89-93.

21. P. Gong, E.J. Palmiere, and W.M. Rainforth: Mater. Charact., 2017, vol. 124, pp. 83-89.

22. E. Orowan: Symposium on Internal Stresses in Metals and Alloys, Institute of Metals, 1948, pp. 451-57.

23. A.W. Thompson: Metall. Trans. A, 1977, vol. 8, pp. 833-42.

24. G.K. Padhy, C.S. Wu, and S. Gao: J. Mater. Sci. Technol, 2018, vol. 34 , pp. $1-38$.

25. W.J. Arbegast: in TMS Annual Meeting on Hot Deformation of Aluminum Alloys III, Z. Jin, A. Beaudoin, T.A. Bieler, and B. Radhakrishnan, eds., Warrendale, PA, USA, 2003, p. 313.

26. D.H. Choi, B.W. Ahn, Y.M. Yeon, S.H.C. Park, Y.S. Sato, H. Kokawa, and S.B. Jung: Mater. Trans. A, 2011, vol. 52, pp. 1500-05.

27. P. Xue, Z.Y. Ma, Y. Komizo, and H. Fujii: Mater. Lett., 2016, vol. 162, pp. 161-64.

28. L.Y. Wei and T.W. Nelson: Mater. Sci. Eng. A, 2012, vol. 556, pp. $51-59$

29. H. Fujii, L. Cui, N. Tsuji, M. Maeda, K. Nakataand, and K. Nogi: Mater. Sci. Eng. A, 2006, vol. 429, pp. 50-57.

30. P. Baillie, S.W. Campbell, A.M. Galloway, S.R. Cater, and N.A. McPherson: Sci. Technol. Weld. Join., 2015, vol. 20, pp. 585-93.

31. D.J. Shindo, A.R. Rivera, and L.E. Murr: J. Mater. Sci., 2002, vol. 37, pp. 4999-5005.

32. Z.Y. Ma, A.H. Feng, B.L. Xiao, J.Z. Fan, and L.K. Shi: Mater. Sci. Forum, 2007, vols. 539-543, pp. 3814-19.

33. A. Azushima, R. Kopp, A. Korhonen, D.Y. Yang, F. Micari, G.D. Lahoti, P. Groche, J. Yanagimoto, N. Tsuj, A. Rosochowski, and A. Yanagida: CIRP Ann. Manuf. Technol., 2008, vol. 57 , pp. 716-35.

34. A. Ohmori, S. Torizuka, K. Nagai, K. Koseki, and Y. Kogo: Mater. Trans., 2004, vol. 45, pp. 2224-31.

35. C. Borchers and R. Kirchheim: Prog. Mater. Sci., 2016, vol. 82, pp. 405-44.

36. F. Wetscher, A. Vorhauer, R. Stock, and R. Pippan: Mater. Sci. Eng. A, 2004, vol. 387, pp. 809-16.

37. M.H. Hong, W.T. Reynolds, T. Tauri, and K. Hono: Metall. Mater. Trans. A, 1999, vol. 30A, pp. 717-27.

38. C.W. Bang, J.B. Seol, Y.S. Yang, and C.G. Park: Scripta Mater., 2015, vol. 108, pp. 151-55

39. G.A. Nematollahi, J.V. Pezold, J. Neugebauer, and D. Raabe: Acta Mater., 2013, vol. 61, pp. 1773-84.

40. V.N. Gridnev and V.G. Garvrilyuk: Phys. Met., 1982, vol. 4, pp. $531-51$.

41. Y. Ivanisenko, W. Lojkowski, R.Z. Valiev, and H.J. Fecht: Acta Mater., 2003, vol. 51, pp. 5555-70.

42. H.K.D.H. Bhadeshia: Philos. Mag., 2013, vol. 93, pp. 3714-25.

43. E.V. Pereloma: Mater. Sci. Technol., 2016, vol. 32, pp. 99-103.

44. C. Aranas, Jr., S.F. Rodrigues, R. Grewal, and J.J. Jonas: ISIJ Int., 2015, vol. 55, pp. 2426-34.

45. H. Yada, C.-M. Li, and H. Yamagata: ISIJ Int., 2000, vol. 40, pp. 200-06.

46. S.-C. Chen, C.-Y. Huang, Y.-T. Wang, and H.-W. Yen: Mater. Des., 2017, vol. 134, pp. 434-45.

47. Y. Matsumura and H. Yada: Trans. Iron Steel Inst. Jpn., 1987, vol. 27 , pp. $492-98$.

48. B. Hutchinson and J. Komenda: Mater. Sci. Technol., 2018, vol. 34, pp. 1197-1200.

49. Y.J. Li, P. Choi, C. Borchers, S. Westerkamp, S. Goto, D. Raabe, and R. Kirchheim: Acta Mater., 2011, vol. 59, pp. 3965-77.

50. D.P. Fairchild, A.J. Wasson, A. Kumar, M.L. Macia, T.D. Anderson, H.W. Jin, R. Ayer, N. Ma, and A. Ozekcin: in 9th International Conference Trends in Welding Research, T. DebRoy, et al., eds., Chicago, 2012, pp. 193-200.

51. F.S. LePera: Metallography, 1979, vol. 12, pp. 263-68. 
52. H.K.D.H. Bhadeshia: Proc. Int. Semin. 'Welding of high strength linepipe steels’, CBMM/TMS, USA, 2013, pp. 99-106.

53. T. Takeyama and E.J. Koepel: Philos. Mag., 1963, vol. 8, pp. 2103-08.

54. T.N. Baker: Acta Metall., 1973, vol. 21, pp. 261-66.

55. V.K. Heikkinen: Scand. J. Metall., 1974, vol. 3, pp. 41-45.

56. H.P. Van Landeghem, M. Véron, S.D. Catteau, J. Teixeira, J. Dulcy, A. Redjaïmia, and S. Denis: Scripta Mater., 2018, vol. 155, pp. 63-67.

57. K. Poorhaydari, B.M. Patchett, and D.G. Ivey: Mater. Sci. Eng. $A, 2006$, vols. 435-436, pp. 371-82.

58. A.T. Davenport: J. Iron Steel Inst., 1968, vol. 206, pp. 499-501.

59. K. Huang and R.E. Logé: Mater. Des., 2016, vol. 111, pp. 548-74.

60. T. Sakai, A. Belyakov, R. Kaibyshev, H. Miura, and J.J. Jonas: Prog. Mater. Sci., 2014, vol. 60, pp. 130-207.

61. J.Q. Su, T.W. Nelson, R. Mishra, and M. Mahoney: Acta Mater., 2003, vol. 51, pp. 713-29.

62. P.A. Beck and P.R. Sperry: J. Appl. Phys., 1950, vol. 21, pp. $150-52$.

63. R.D. Doherty, D.A. Hughes, F.J. Humphreys, J.J. Jonas, D. Juul Jensen, M.E. Kassner, W.E. King, T.R. McNelly, H.J. McQueen, and A.D. Rollett: Mater. Sci. Eng. A, 1997, vol. 238, pp. 219-74.

64. K. Huang, K. Marthinsen, Q. Zhao, and R.E. Logé: Prog. Mater. Sci., 2018, vol. 92, pp. 284-359.

65. T.N. Baker and N.A. McPherson: Met. Sci., 1979, vol. 13, pp. 611-18

66. S.G. Hong, K.B. Kang, and C.G. Park: Scripta Mater., 2002, vol. 46, pp. 163-68.

67. S. Shanmugam, R.D.K. Misra, T. Mannering, D. Panda, and S.G. Jansto: Mater. Sci. Eng. A, 2006, vol. 437, pp. 436-45.

68. Z. Wang, X. Mao, Z. Yanga, X. Sun, Q. Yong, Z. Li, and Y. Weng: Mater. Sci. Eng. A, 2011, vol. 529, pp. 459-67.

69. J. Cheng, J. Qing, and H.F. Shen: Strength Mater., 2018, vol. 50, pp. 218-28.
70. K. Xu, B.G. Thomas, and R. O'Malley: Metall. Mater. Trans. A, 2011, vol. 42A, pp. 524-39.

71. S.F. Medina, A. Quispe, and M. Gomez: Metall. Mater. Trans. A, 2014, vol. 45A, pp. 1524-39.

72. A.T. Davenport, L.C. Brossard, and R.E. Miner: J. Met., 1975, vol. 27, pp. 21-27.

73. W.B. Lee, S.G. Hong, C.G. Park, K.H. Kim, and S.H. Park: Scripta Mater., 2000, vol. 43, pp. 319-24.

74. M. Nöhrer, W. Mayer, S. Zamberger, E. Kozeschnik, and H. Leitner: Steel Res. Int., 2014, vol. 85, pp. 679-88.

75. S. Zajac: Mater. Sci. Forum, 2005, vols. 500-501, pp. 75-86.

76. A. Kelly and R.B. Nicholson: Prog. Mater. Sci., 1963, vol. 10, pp. 149-391.

77. H. Gleiter and E. Hornbogen: Mater. Sci. Eng., 1967/1968, vol. 2, pp. 285-302.

78. A.J. Ardell: Metall. Trans. A, 1985, vol. 16, pp. 2131-65.

79. J.W. Martin and R.D. Doherty: Stability of Microstructure in Metallic Systems, Cambridge University Press, Cambridge, 1976, pp. $270-75$.

80. B. Yang, Y.T. Zhou, D. Chen, and X.L. Ma: Sci. Rep., 2013, vol. 3, p. 1039.

81. T.N. Baker and A.J. Lapointe: in Developments in Electron Microscopy and Analysis, D.L. Misell, ed., Institute of Physics, London, 1977, pp. 195-98.

82. S.L. Sass, T. Mura, and J.B. Cohen: Philos. Mag., 1967, vol. 16, pp. 679-90.

83. T.N. Baker: Ironmak. Steelmak., 2016, vol. 43, pp. 264-307.

84. K. Narita: Trans. Iron Steel Inst. Jpn., 1975, vol. 15, pp. 145-52.

85. T. Gladman: Microalloyed Steels, Institute of Materials, London, 1997.

86. K.A. Taylor: Scripta Metall. Mater., 1995, vol. 32, pp. 7-12.

Publisher's Note Springer Nature remains neutral with regard to jurisdictional claims in published maps and institutional affiliations. 